GEOHYDROLOGY AND SUSCEPTIBILITY OF MAJOR AQUIFERS

TO SURFACE CONTAMINATION IN ALABAMA; AREA 7

by Will s. Mooty

U.S. GEOLOGICAL SURVEY

Water-Resources Investigations Report 87-4109

Prepared in cooperation with the

ALABAMA DEPARTMENT OF ENVIRONMENTAL MANAGEMENT

Tuscaloosa, Alabama 
DEPARTMENT OF THE INTERIOR

DONALD PAUL HODEL, Secretary

U.S. GEOLOGICAL SURVEY

Dallas L. Peck, Director

For additional information write to:

District Chief

U.S. Geological Survey

52019 th Avenue

Tuscaloosa, Alabama 35401
Copies of this report can be purchased from:

U.S. Geological Survey Books and Open-File Reports Section Federal Center, Box 25425

Denver, Colorado 80225 
Abstract................................................

Introduction............................................

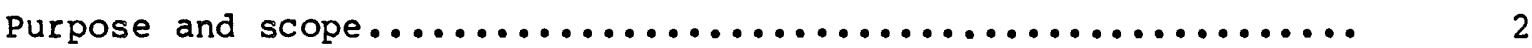

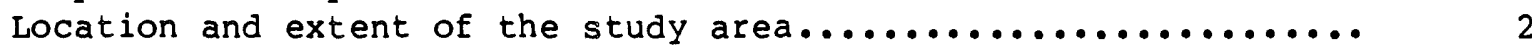

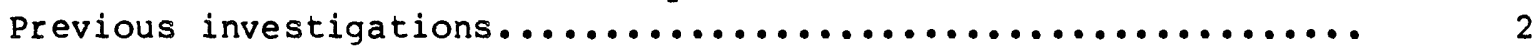

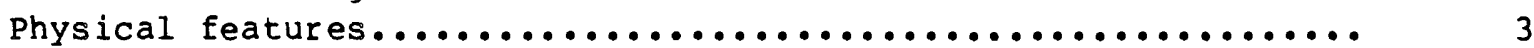

Acknowledgments.......................................

Geohydrology.............................................6

Paleozoic rocks....................................... 6

Cretaceous formations................................. 8

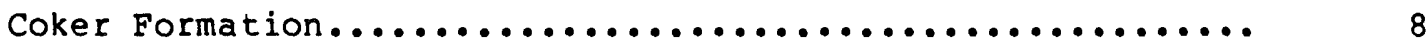

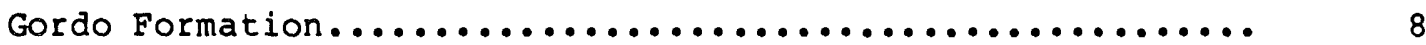

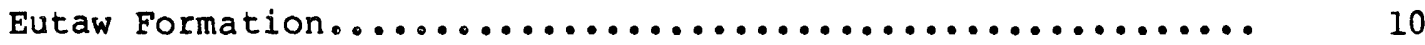

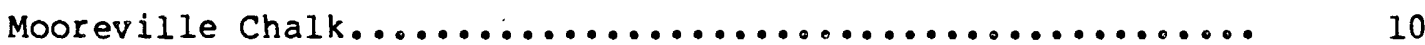

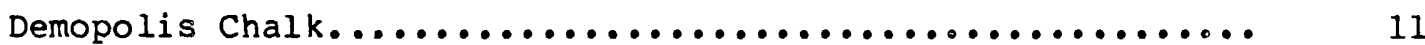

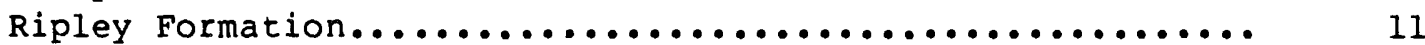

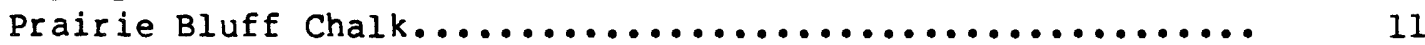

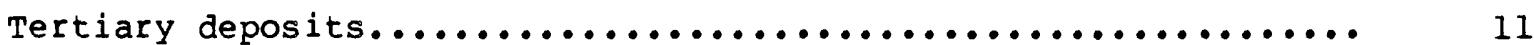

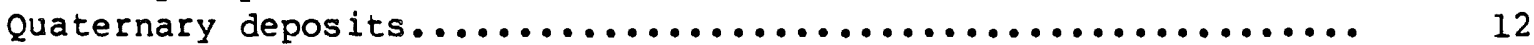

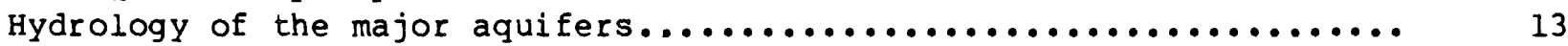

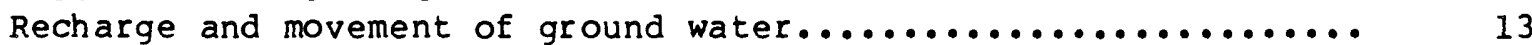

Natural discharge and ground-water withdrawals.............. 14

Effects of withdrawals from the aquifers................... 15

Susceptibility of the aquifers to land surface contamination........ 15

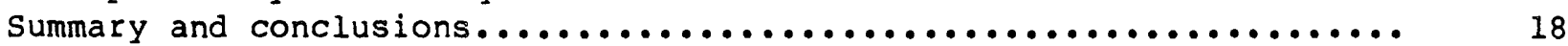

Selected references....................................... 19 


\section{ILLUSTRATIONS}

Page

Plate 1. Map of the study area showing recharge areas of the major aquifers (areas susceptible to contamination), potentiometric surfaces, and locations of public water-supply wells.......................... in back

Figure 1. Map showing physiographic regions of the study area.......

2. Map showing generalized geology of the study area....... 7

3. Generalized geohydrologic section of the study area....... 9 9

4. Map showing areas highly susceptible to ground-water contamination.

\section{TABLES}

Table 1. Records of public water-supply wells and springs

in the study area............................... 21

2. Geologic units and their water-bearing properties........ 26 


\section{CONVERSION FACTORS}

For use of readers who prefer to use metric (International system) units, conversion factors for inch-pound units used in this report are listed below:

\begin{tabular}{|c|c|c|}
\hline Multiply inch-pound unit & $\underline{\text { By }}$ & To obtain metric unit \\
\hline inch (in.) & 25.4 & millimeter $(\mathrm{mm})$ \\
\hline foot $(f t)$ & 0.3048 & meter (m) \\
\hline mile (mi) & 1.609 & kilometer $(\mathrm{km})$ \\
\hline $\begin{array}{l}\text { cubic foot per second } \\
\text { per square mile } \\
{\left[(\mathrm{ft} 3 / \mathrm{s}) / \mathrm{mi}^{2]}\right.}\end{array}$ & 0.01093 & $\begin{array}{l}\text { cubic meter per second } \\
\text { per square kilometer } \\
{\left[\left(\mathrm{m}^{3} / \mathrm{s}\right) / \mathrm{km}^{2}\right]}\end{array}$ \\
\hline $\begin{array}{l}\text { gallon per minute } \\
\text { (gal/min) }\end{array}$ & 0.06308 & $\begin{array}{l}\text { 1iter per second } \\
(\mathrm{L} / \mathrm{s})\end{array}$ \\
\hline $\begin{array}{l}\text { million gallon per day } \\
\text { (Mgal/d) }\end{array}$ & 0.04381 & $\begin{array}{c}\text { cubic meter per second } \\
\left(\mathrm{m}^{3} / \mathrm{s}\right)\end{array}$ \\
\hline
\end{tabular}

Sea leve1: In this report "sea leve1" refers to the National Geodetic Vertical Datum of 1929 (NGVD of 1929)--a geodetic datum derived from a general adjustment of the first-order level nets of both the United States and Canada, formerly called "Mean Sea Level of 1929." 


\title{
GEOHYDROLOGY AND SUSCEPTIBILITY OF MAJOR AQUIFERS TO SURFACE CONTAMINATION IN ALABAMA; AREA 7
}

\author{
By Will s. Mooty
}

\section{ABSTRACT}

The U.S. Geological Survey, in cooperation with the Alabama Department of Environmental Management, is conducting a series of geohydrologic studies to delineate the major aquifers and their susceptibility to land surface contamination in Alabama. The geohydrology and susceptibility to land surface contamination of the seven major aquifers in Area 7--Bibb, Dallas, Hale, Perry, and Wilcox Counties are described in this report. Aquifers in the northern part of the study area are in Paleozoic limestone and dolomite formations. Deposits in the central part of the study area are predominately of Cretaceous age and contain the coker, Gordo, and Eutaw aquifers. Although the southern part of the study area has many deposits of Tertiary age, the Ripley Formation of Cretaceous age is the major aquifer. The recharge area for each aquifer is roughly equivalent to its outcrop area.

The major Paleozoic limestone and dolomite aquifers are in the Conasauga Formation and the Copper Ridge and Chepultepec Dolomites of the Knox Group. In these formations, ground water occurs in secondary openings that are along solutionally enlarged fractures and joints, and in caverns. Sinkholes, often a direct link from the land surface to the water table, are common in this area. The susceptibility of these aquifers to surface contamination is high because of the direct link that sinkholes provide and because of the high permeability of the soils and the downstream location of much of the recharge area from the large metropolitan areas of the neighboring counties. Groundwater movement generally follows the direction of the streams and valleys in the area.

The Coker, Gordo, Eutaw, and Ripley aquifers are of Cretaceous age. They are composed of unconsolidated clastic deposits with intergranular porosity. These aquifers may yield up to 1,500 gallons per minute to properly constructed wel1s. Ground-water movement in the central and southern part of the study area generally is downdip to the southwest. Although the characteristics of these aquifers make them susceptible to contamination, recharge occurs in predominantly rural areas that makes the probability of contamination unlikely. However, the susceptibility of these aquifers to contamination also is high in areas of sinkholes or where flat terrain increases the rate of recharge to the aquifers.

The alluvial and terrace deposits along the major rivers are normally areas of ground-water discharge. However, if enough ground-water withdrawal occurred in these deposits, they would change from an area of discharge to an area of recharge. Due to the permeability of these deposits and the flat terrain where they occur, these areas would be highly susceptible to surface contamination. 


\section{INTRODUCTION}

The Alabama Department of Environmental Management (ADEM) is developing a comprehensive program to protect aquifers in Alabama from land surface contamination. These aquifers are defined by the U.S. Environmental Protection Agency (EPA) as "Class I or II" aquifers (U.S. Environmental Protection Agency, 1984). The U.S. Geological Survey, in cooperation with ADEM, is conducting a series of geohydrologic studies in Alabama to delineate the major aquifers and their recharge areas, and to define areas susceptible to land surface contamination. This report summarizes these factors for major aquifers in Area 7-Bibb, Dallas, Hale, Perry, and Wilcox Counties.

\section{Purpose and Scope}

The purpose of this report is to describe the geohydrology of the major aquifers and their susceptibility to contamination from land surface. Geologic and hydrologic data compiled as part of previous investigations provided about 80 percent of the data used to evaluate the major aquifers in the area. All wells used for municipal and rural public water supplies were inventoried, and water levels were measured in these wells where possible. Data on water use were compiled during the well inventory. Water-level data from the Regional Aquifer System Analysis inventory were used to compile generalized potentiometric maps of the aquifers. Areas susceptible to contamination from the land surface were delineated from topographic maps, geologic maps, field investigations, and other pertinent data.

\section{Location and Extent of the Study Area}

Study Area 7 is in west-central Alabama and encompasses an area of about 3,892 square miles (Alabama Dept. of Economic and Community Affairs, 1984). The area includes the city of Selma, the towns of Brent, Centreville, Greensboro, Marion, Uniontown, West Blocton, Camden, and numerous other small towns and communities (see plate 1). The total population of the area was 115,075 in 1980 (U.S. Bureau of the Census, 1982). The area is predominately rural. The city of selma is the largest urban center within the area with a population of 26,684 . The remaining towns and communities each have a population of less than 5,000. The primary source for public water supplies in the area is ground water.

\section{Previous Investigations}

Numerous reports that describe the geology and ground-water resources of the study area have been published. A detailed description of the geology of Alabama and a revised geologic map were published by the Alabama Geological Survey in 1926 (Adams and others, 1926). 
Other reports that contain information on the geology and ground-water resources of the area are "Geology of the Alabama Coastal plain" (Copeland, 1968): "Notes on Deposits of Se1ma and Ripley Age in Alabama" (Monroe, 1941); "Geology and Ground-Water Resources of Wilcox County, Alabama" (LaMoreaux and Toulmin, 1959); "Ground-Water Resources of the Cretaceous Area of Alabama" (Carlston, 1944); "The Physical Setting" (Moore, 1976); "Geology and Water Availability of Dallas County, Alabama" (Scott and others, 1981); "Water Availability and Geology of Hale County, Alabama" (Davis and others, 1975); "Water Availability in Bibb County, Alabama" (Causey and others, 1978); "Mineral, Water, and Energy Resources of Wilcox County, Alabama" (Geological Survey of Alabama, 1969); "Water Availability in Perry County, Alabama" (Reed and others, 1972); "Geology of Perry County, Alabama" (Reed, 1972): "Areal Geology of Jefferson County, Alabama, Atlas 15" (Kidd, 1979); and "Engineering Geology of Jefferson County, Alabama, Atlas 14" (Szabo and others, 1979).

\section{Physical Features}

Study Area 7 lies entirely within the East Gulf Coastal plain physiographic section except for the northeastern one-third of Bibb County, which is in the Alabama Valley and Ridge physiographic section (fig. 1). The northeastern section of Bibb County consists of the Birmingham-Big Canoe Valley, Cahaba Ridges, and Cahaba Valley districts (Sapp and Emplaincourt, 1975). The Alabama Valley and Ridge physiographic section consists mainly of northeastward-trending ridges and valleys. The altitudes of valley floors are about 400 feet above sea level and the ridges are about 600 feet above sea leve1. Drainage in the area is southward to the Cahaba River.

Southwestern Bibb County and northern Hale, Dallas, and Perry Counties are in the Fall Line Hills district of the East Gulf Coastal Plain physiographic section. This area mainly consists of flat to moderately rolling sandy uplands dissected by deeply entrenched southward-flowing streams. The land surface ranges in altitude from about 250 feet above sea level at the town of Greensboro to about 625 feet above sea level near the junction of Bibb, Hale, and Tuscaloosa Counties.

Parts of Hale County near the Black Warrior River, and parts of Bibb, Perry, Dallas, and Wilcox Counties near the Cahaba and Alabama Rivers are in the Alluvial-Deltaic Plain district of the East Gulf Coastal Plain physiographic section. This area is characterized by broad, flat flood plains and terraces. Much of the area is periodically inundated by floods on these rivers. The land surface ranges in altitude from about 250 feet above sea level at the town of Centreville to about 50 feet above sea level near the community of Lower Peach Tree.

Southern Hale and Perry Counties and parts of central and southern Dallas County are in the Black Prairie district of the East Gulf Coastal Plain physiographic section. The Black Prairie, named for the black soil that is common in the area, is a gently- to moderately-rolling prairie that is characterized by extensive grasslands and few trees. The land surface in the area ranges from about 250 feet above sea level at the town of Uniontown to 
EXPLANATION

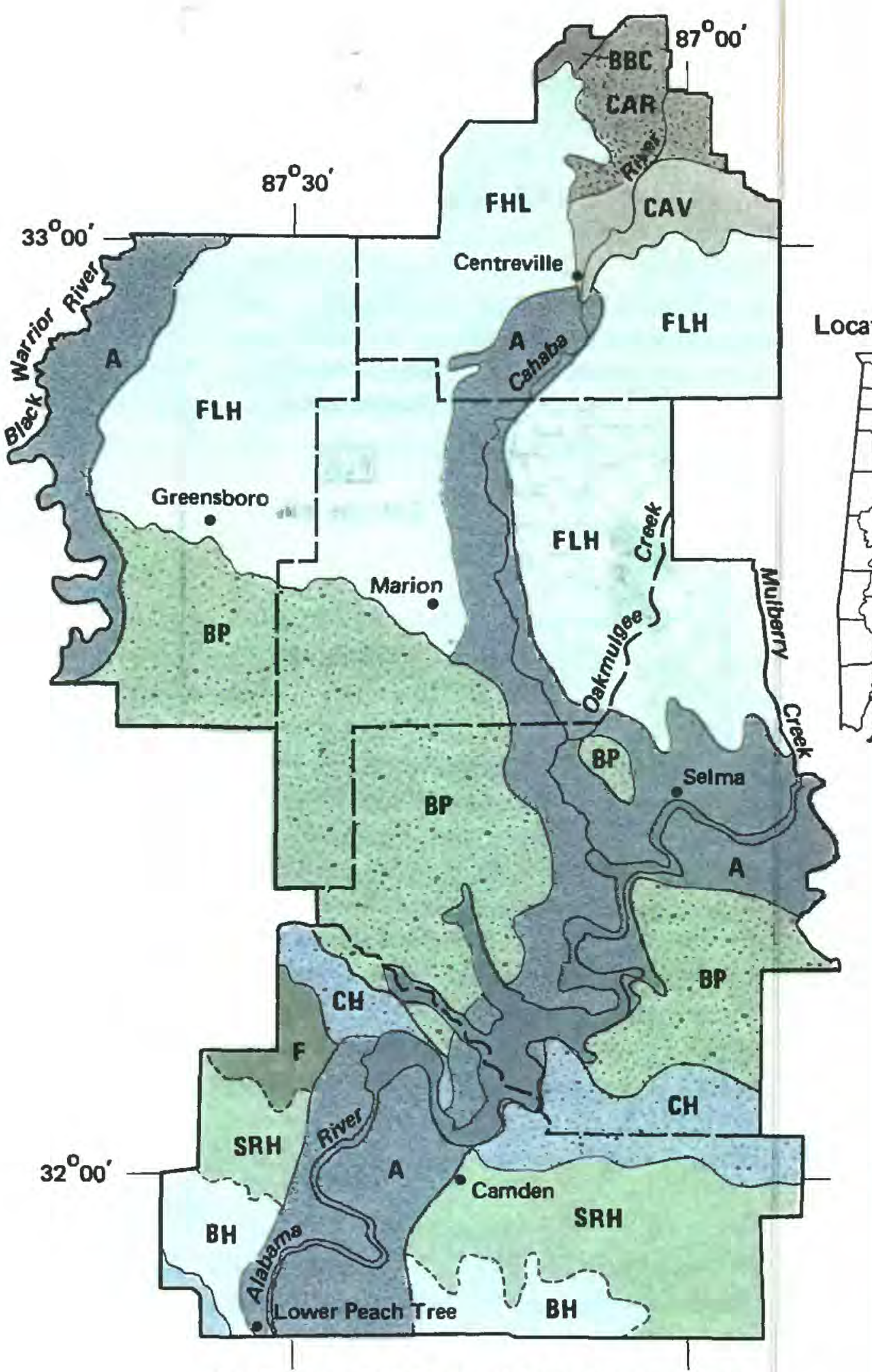

Modified from C.D. Sapp and J. Emplaincourt, 1975

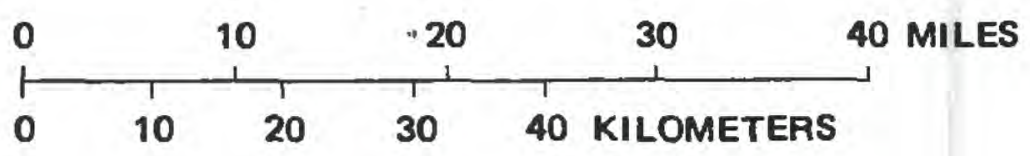

\section{PHYSIOGRAPHIC DISTRICTS \\ PHYSIOGRAPHIC DISTRICTS}

CAV
Cahaba Valley
Cahaba Ridges
Birmingham-Big
Canoe Valley

$$
\begin{aligned}
& \text { FLH } \\
& \text { Fall Line Hills }
\end{aligned}
$$

Black Prairie

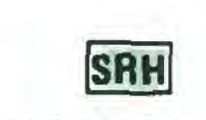

Southern Red Hills

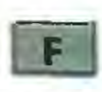

Flatwoods Subdistrict

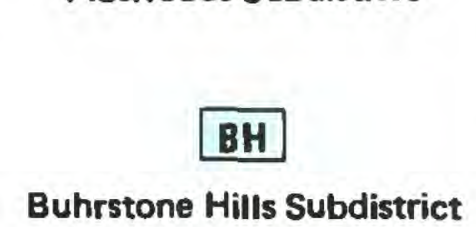

Buhrstone Hills Subdistric

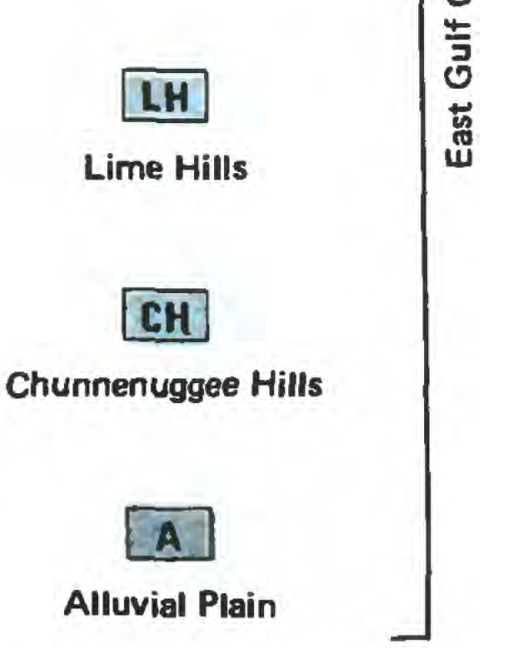

- BOUNDARY OF PHYSIOGRAPHIC DISTRICT -- BOUNDARY OF PHYSIOGRAPHIC SUBDISTRICT

Figure 1.--Physiographic regions of the study area. 
about 150 feet above sea level near Greensboro. Drainage in the Black Prairie is generally westward to the Black Warrior River and southeastward to the Cahaba and Alabama Rivers.

Parts of northern wilcox and southern Dallas counties are in the Chunnenuggee Hills district of the East Gulf Coastal Plain physiographic section. This area is characterized by the sandy cuestas that have fairly steep northward facing escarpments and gently- to moderately-rolling backslopes. The land surface in the area ranges from about 200 to 300 feet above sea leve1. Drainage in the area is northward along the escarpments of the cuestas, and southward along the backslopes.

Parts of southern Wilcox County are in the Buhrstone Hills subdistrict of the Southern Red Hills district of the East Gulf Coastal Plain physiographic section. This is considered to be the most rugged topographic region in the Alabama coastal plain. It is a 10-mile wide hilly belt that is 200 to 300 feet above nearby streams.

A small part of east-central wilcox County lies in the Flatwoods subdistrict of the Southern Red Hills district of the East Gulf Coastal Plain physiographic section. This 5 to 8 mile wide band has a relatively smooth surface with an altitude of about 150 to 200 feet above sea leve1. Drainage is to the northwest towards the Alabama River.

A 10-mile wide band through central wilcox County lies in the Southern Red Hills district of the East Gulf Coastal Plain physiographic section. The area is characterized by a nearly plane horizon formed by the land surface that gently slopes to the south and west. Altitudes of the inner edge of the area range from 300 to 550 feet above sea level throughout its length. Because the plain is high above the adjacent lowlands, streams cutting through the plain provide reliefs of several hundred feet.

A smal1 part of southwestern wilcox County is in the Lime Hills district of the East Gulf Coastal plain physiographic section. This area will not be discussed in the report because of the area's small size and lack of any major water systems.

\section{Acknowledgments}

The author wishes to thank J. E. Crownover and N. A. Derryberry for their assistance during the field investigations and preparation of this report. Appreciation also is extended to the managers of the ground-water systems in the study area for their help in locating public-supply wells and furnishing information on well construction and water use. 


\section{GEOHYDROLOGY}

Geologic formations that crop out in and underlie the study area range in age from Cambrian to Quaternary (table 2). Consolidated sedimentary rocks of Paleozoic age crop out in northern Bibb County. These rocks range in age from Cambrian to Pennsylvanian. The remaining part of the study area is within the East Gulf Coastal plain that consists of unconsolidated sedimentary deposits of Late Cretaceous age and younger. Sediments of Late Cretaceous age crop out in southern Bibb and northern Dallas, Hale, and perry Counties. Unconsolidated sedimentary rocks of Tertiary age crop out in wilcox county and in a small part of Dallas County. Alluvial and terrace deposits of Quaternary age overlie the older rocks in and adjacent to the flood plains of the Black Warrior, Cahaba, and Alabama Rivers and some of the larger streams in the study area (fig. 2 ).

The discussions on the Cretaceous and Tertiary deposits in Area 7 are derived from reports by Monroe (1941), Carlston (1944), Copeland (1968), Moore (1976), and scott and others (1981).

\section{Paleozoic Rocks}

Sedimentary rocks that range in age from Cambrian to Pennsylvanian crop out in northern Bibb county (fig. 2). Geologic units from oldest to youngest include; the Rome and Conasauga Formations, Brierfield, Ketona, and Bibb Dolomites of Cambrian age; the Knox Dolomite or Knox Group where it is divided and includes the Copper Ridge Dolomite, Chepultepec Dolomite, Longview Limestone, and Newala Limestone of Cambrian and|Ordovician age; the Lenoir and Chickamauga Limestones, and Athens Shale of Ordovician age; the Red Mountain Formation of Silurian age; the Frog Mountain Sandstone and Chattanooga Shale of Devonian age; the Fort Payne Chert and the Floyd Shale of Mississippian age; the Parkwood Formation of Mississippian and Pennsylvanian age; and the Pottsville Formation of Pennsylvanian age (Ed Osborn, Geological survey of Alabama, oral commun.; Szabo, 1979). These rocks crop out in an area of about 175 to 200 square miles in northern Bibb County and are complexly folded and faulted.

Large-capacity wells in the area are in dolomite and limestone formations. These wells may produce as much as $350 \mathrm{gal} / \mathrm{min}$ (gallons per minute) in the higher yielding formations. For example, a well developed in the Conasauga Formation in the town of Green Pond in northern Bibb County had a drawdown of only 11 feet after 40 days of pumping at a tate of $170 \mathrm{gal} / \mathrm{min}$ in 1966 . A municipal spring discharging from the Copper Ridge Dolomite near the town of West Blocton had an estimated flow of $750 \mathrm{ga} 1 / \mathrm{min}$ in 1967 (Causey and others, 1978). Wells completed in the pottsville Formation generally produce less than $70 \mathrm{gal} / \mathrm{min}$. 


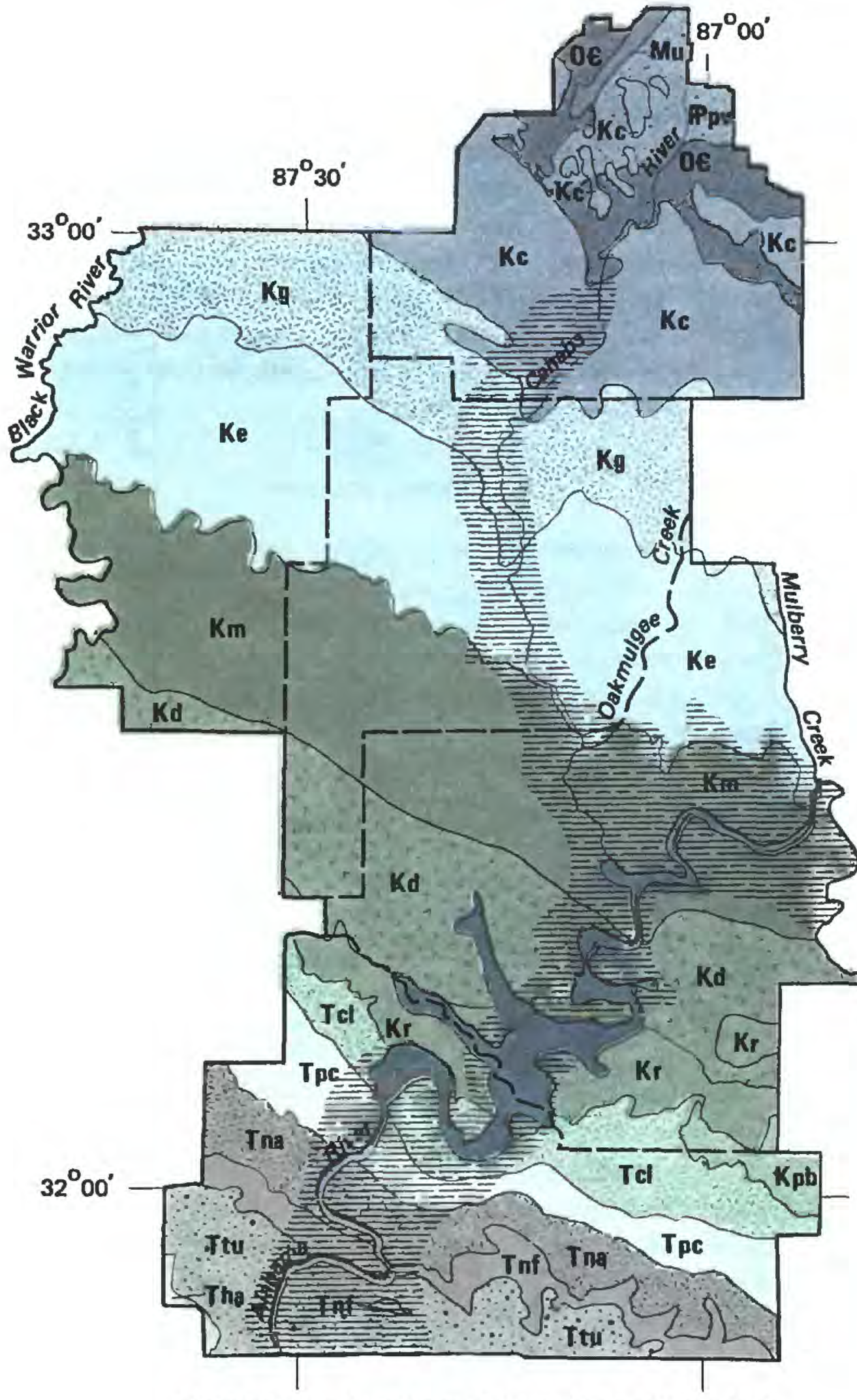

Modified from M. E. Davis, 1980, and G. I. Adams, 1926

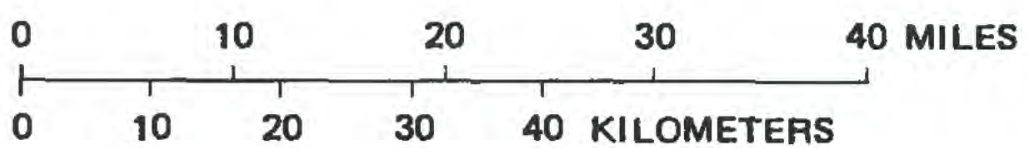

\section{GEOLOGIC UNITS}

Areas overlain by alluvial and terrace deposits

Hatchetigbee Formation

Fitu.

Tuscahoma Sand

Tnf

Nanafalia Formation

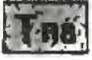

Naheola Formation

Tpc

Porters Creek Formation

TCl

Clayton Formation

$\mathrm{Kpb}$

Prairie Bluff Chalk

Kr

Ripley Formation

$\mathrm{Kd}$

Demopolis Chalk

$\mathrm{Km}$

Mooreville Chalk

Ke

Eutaw Formation

$\mathrm{Kg}$

Gordo Formation

Kc

Coker Formation

Ppy

Pottsville Formation

Mil

Upper Mississippian formations

06

Ordovician and Cambrian formations

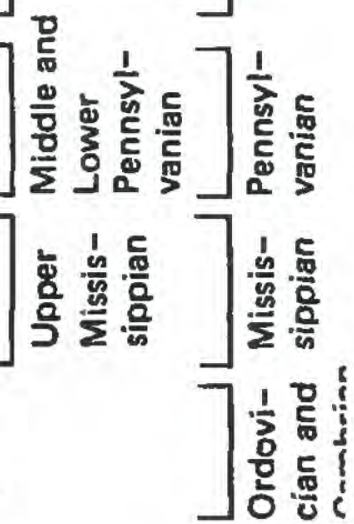

Figure 2.--Generalized geology of the study area. 
Sedimentary deposits of Late Cretaceous age overlie the Paleozoic rocks throughout all of Hale and Perry Counties, most of Bibb and Dallas Counties, and a small part of Wilcox County. These deposits include, from the oldest to the youngest: the coker and Gordo Formations of the Tuscaloosa Group: the Eutaw Formation; the Mooreville and Demopolis Chalks, the Ripley Formation, and the Prairie Bluff Chalk of the Selma Group. These formations strike southeastward and dip south to southwest at 30 to 50 feet per mile. They consist of sedimentary deposits of sand, gravel, clay, and chalk, most of which were deposited in relatively shallow marine waters, but some of which were deposited by streams on low plains that bordered the coast.

\section{Coker Formation}

The Coker Formation crops out in central Bibb county and a small part of northern Hale and Perry Counties (fig. 2). The coker underlies all of the study area south of its outcrop area and is one of the major aquifers in the northern half of the study area. The coker Formation ranges in thickness from 600 feet at its outcrop to 1,100 feet in the subsurface in the southern part of the study area (Kidd, 1976). The Coker consists of basal nonmarine zone of sand, grave1, and clay that was deposited in a deltaic environment. The coarser sand beds and the beds of gravel are near the bottom of the formation. The beds are about 25 feet thick and in places more than 100 feet thick. The gravel contains large amounts of quartz pebbles derived from the underlying Pottsville Formation. The upper part of the formation consists chiefly of clay and sandy clay containing some lenses of micaceous and glauconitic sand. A clay zone is usually present at the top of the coker. This clay is a confining unit between the coker aquifer and the overlying Gordo aquifer fig. 3).

The coarse sand and gravel beds of the coker are developed for public water supplies by the city of Selma, by the towns of Plantersville and Moundville, and by the county system for Perry county. It has not been developed as a source of water supply south of Selma due to the excessive depth of the aquifer where the much shallower Gordo and Eutaw aquifers are available. Wells that tap the Coker have a potential production capacity of $1,000 \mathrm{gal} / \mathrm{min}$ in some areas, but most wells are pumped at $200 \mathrm{gal} / \mathrm{min}$ or 1 ess.

The chloride concentration of water in the coker aquifer is less than $250 \mathrm{mg} / \mathrm{L}$ (milligrams per liter), except in parts of Hale County near the Black Warrior River and farther downdip in Wilcox County.

\section{Gordo Formation}

The Gordo Formation overlies the coker and underlies all of the study area south of its outcrop in northeastern Hale county, southern Bibb County, northern Perry County, and northeastern Dallas County (figs. 2 and 3). The Gordo consists of a massive clay bed overlying alternating beds of sand and varicolored mottled clay with a basal zone of gravelly sand. The Gordo ranges in thickness from about 100 feet at its outcrop to more than 400 feet in the subsurface in the southern part of the study area. 


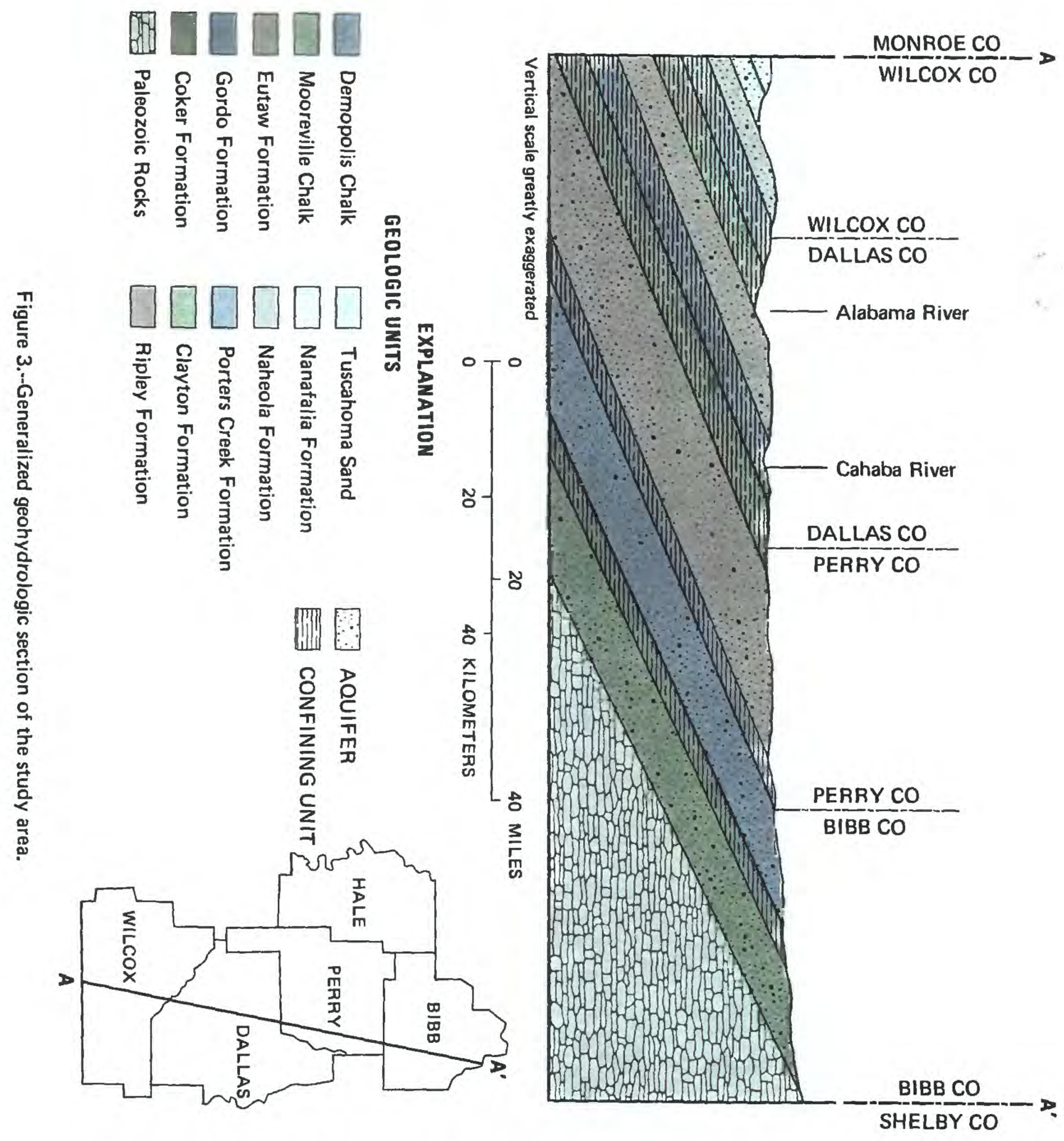


The Gordo is one of the major aquifers in the study area. It is a principal source of water for the city of Selma; the towns of Greensboro, Moundville, and Marion; and the North Dallas County and Dallas County water systems. The Gordo is not a major source of water in Bibb county because it crops out in the southern part of the county where there are no major water systems. Also, it is not used in Wilcox County where the depth to the aquifer and the high chloride concentration of the water make it undesirable as a source of public water. Wells developed solely in the Gordo aquifer produce from 200 to $1,000 \mathrm{gal} / \mathrm{min}$.

\section{Eutaw Formation}

The Eutaw Formation overlies the Gordoland crops out in extreme southwestern Bibb County, central Hale and Perry Counties, and northeastern Dallas County (fig. 2). The Eutaw consists of glauconitic sand and clay beds, which were deposited in a shallow marine environment. The maximum thickness of the formation is about 400 feet. The lower part of the formation consists of 30 to 50 feet of glauconitic sand interbedded with sandy clay. The middle part consists of 50 to 150 feet of calcareous clay and sandy clay. The upper part consists of as much as 150 feet of massive glauconitic sand interbedded with calcareous and sandy limestone.

The Eutaw is a major source of water in the southern parts of Hale and Perry Counties and all of Dallas County. Most of the public water systems in these counties pump water from the sand beds of this aquifer. The Eutaw is a potential source of water in northern Wilcox County, but because of its excessive depth and the availability of water in more shallow aquifers, the aquifer is not used. Ch1oride concentrations. in the Eutaw downgradient from central wilcox County reach undesirable levels and, thus, eliminates it as a source of public water supply in that area.

We11s developed in the Eutaw aquifer are capable of producing as much as $1,500 \mathrm{gal} / \mathrm{min}$ as reported from aquifer tests on two wells in selma. Many flowing artesian wells are completed in the Eutaw in the study area; most of these wells have free flows of 10 to $30 \mathrm{ga} 1 / \mathrm{min}$, but some flow as much as 100 $\mathrm{gal} / \mathrm{min}$ (Scott and others, 1981).

\section{Mooreville Chalk}

The Mooreville Chalk crops out in southern Hale County, southwestern Perry County, and across most of central Dallas county (fig. 2). It is up to 420 feet thick. The Mooreville Chalk was formed in warm, shallow seas so that microfossils compose a large percentage of the chalk. It unconformably over1 ies the Eutaw Formation and includes an unnamed member at the bottom and the Arcola Limestone Member at the top. The Mooreville consists of compact, very calcareous clay, marl, and clayey chalk. At some places the contact appears to be gradational. The unconformable contacts are characterized by a bed of sandy glauconitic chalk from 6 to 12 inches thick at the base of the Mooreville chalk that contains abundant shark teeth and phosphatized molds of fossils. In some areas, fine glauconitic sand and clay beds of the Eutaw Formation grade upward into fine glauconitic chalk beds of the Mooreville. The Mooreville is relatively impermeable and is not an aquifer in the study area. 
The Demopolis Chalk overlies the Mooreville Chalk and crops out in extreme southern Hale County, southwestern Perry County, and southern Dallas County (fig. 2). The Demopolis consists of up to 440 feet of chalk, calcareous clay, and sandy clay. The Demopolis is relatively impermeable and is not an aquifer in the study area.

\section{Ripley Formation}

The Ripley Formation overlies the Demopolis Chalk and crops out in extreme southern Perry County, southern Dallas County, and extreme northeastern and northwestern wilcox County. The Ripley consists of beds of calcareous sandstone, sandy chalk, sand, sandy calcareous clays, and thin beds of fossiliferous sandstone. The Ripley ranges from 100 to 300 feet in thickness. It is tapped by a few private wells in southern Dallas County. The towns of Camden and Pine Apple in Wilcox County tap it as their source of public water supply. Reported yields range from less than 10 to $120 \mathrm{gal} / \mathrm{min}$.

\section{Prairie Bluff Chalk}

The Prairie Bluff Chalk overlies the Ripley Formation and crops out immediately south of and parallel to the Ripley in southeastern Dallas County and northern Wilcox County. The Prairie Bluff Chalk consists of fossiliferous sandy chalk and calcareous sandy clay. It ranges in thickness from 10 to 60 feet. The prairie Bluff is relatively impermeable and is not an aquifer in the study area.

\section{Tertiary Deposits}

Tertiary deposits in the study area are limited to a small part of southern Dallas County and most of Wilcox County. Most of the sediments consist of sand, clay, mud, or calcareous ooze deposited on the sea bottom at this time. Some sediments in outcrops show evidence of having been deposited in swamps, marshes, lagoons, or on flood plains. These deposits include, from the oldest to the youngest, the clayton Formation, the Porters creek Formation, the Naheola Formation, the Nanafalia Formation, the Tuscahoma Sand, the Hatchetigbee Formation, and the Tallahatta Formation.

The Clayton, Porters Creek, Naheola, and Nanafalia Formations, and the Tuscahoma Sand are of Paleocene age. The clayton Formation crops out across northern Wilcox County. It is subdivided into the lower Pine Barren Member consisting of about 160 feet of calcareous silt and fine sand, and the upper MCBride Limestone Member, consisting of about 60 feet of limestone and chalky clay. The formation thins rapidly westward. The clayton Formation is not an aquifer in the study area.

The Porters Creek Formation crops out in a band across central Wilcox County. It consists of a lower unnamed member and the upper Matthews Landing Marl Member. The lower member consists of about 100 to 200 feet of gray, 
blocky clay with some sand in the upper 50 feet. The upper member consists of about 20 feet of green-brown sandy clay and silt with interbeds of calcareous sandstone. The porters Creek Formation is not an aquifer in the study area.

The Naheola Formation crops out intermittently across central Wilcox County. It is about 200 feet thick near the Alabama River and thins to about 80 feet in eastern Wilcox County. The lower member, the Oak Hill Member, consists of laminated, silty, clay containing interbeds of fine-grained sand and a thin bed of lignite near the top. The upper member, the Coal Bluff Mar1 Member, consists of laminated sand and clay about 20 to 40 feet thick. The Naheola Formation is not a major aquifer in the study area.

The Nanafalia crops out in west-central and southern wilcox County. It is up to 200 feet thick and is divided into three members. The basal member, the Gravel Creek Sand Member, consists of medium- to fine-grained, crossbedded sand with lenses of fine gravel. It is less than 60 feet thick. The middle member, the fossiliferous "Ostrea Thirsae beds," consists of silty clay, calcareous sand, and sandy shell marl about 30 to 60 feet thick. The upper member, the Grampian Hills Member, consists of 80 to 110 feet of yellowishgreen to gray indurated clay and claystone. Within the claystone are lenses of coarse glauconitic sand.

The Tuscahoma Sand crops out in southwestern and south-central wilcox county. Its thickness is about 275 feet and consists of nonfossiliferous gray interlaminated fine-grained sand and clayey silt. The basal sand beds are about 60 feet thick and are fine-grained and olive-gray to green in color. The upper member, the Bells Landing Marl Member is 6 to 10 feet thick along the Alabama River.

The Hatchetigbee and Tallahatta Formations are of Eocene age. Together, the Hatchetigbee and Tallahatta Formations and the Tuscahoma Sand comprise the part of the Lisbon aquifer that is within the study area. The Lisbon is a major aquifer south of the study area. The Hatchetigbee overlies the Tuscahoma Sand and ranges from about 200 to 300 feet thick and consists of fine- to medium-grained, calcareous sand with interlaminated clay and shale; it crops out in a small area of southwestern wilcox County. The Tallahatta Formation occurs in small outliers in extreme southwestern Wilcox county.

None of the Tertiary deposits are major aquifers within the study area, but are major aquifers further downdip in Monroe and clarke Counties where several public water systems tap them. Some private wells in Wilcox County tap the major aquifers in the Nanafalia, Clayton, and Tuscahoma Formations.

\section{Quaternary Deposits}

Quaternary deposits overlie older formations throughout a large part of the study area. These deposits consist of alluvial sediments and terrace deposits associated with the flood plains of present and ancestral large streams. They consist main1y of gravel, sand, silt, and clay. The alluvial deposits generally range in thickness from 0 to 60 feet, but are as much as 80 feet thick in some places. Terrace deposits are up to 100 feet thick. 
The alluvial deposits are a potential source of water for large supplies in the flood plains of the major rivers in the area but have not been developed for public water supply systems.

\section{HYDROLOGY OF THE MAJOR AQUIFERS}

The major aquifers in the study area are the limestones and dolomites of the Conasauga Formation and the Copper Ridge and Chepultepec Dolomites of the Knox group, and the sand and gravel beds of the Coker, Gordo, Eutaw, and Ripley Formations.

On1y a small part of southwestern Wilcox County recharges the Lisbon aquifer in the Lisbon Formation. Because the Lisbon is not a major aquifer in the study area, it will not be discussed in this report. The Lisbon is a major aquifer south of the study area.

\section{Recharge and Movement of Ground Water}

The source of recharge to the major aquifers is precipitation which averages about 50 to 60 inches per year in the study area (National oceanic and Atmospheric Administration, 1985). The recharge area for each aquifer is approximately equivalent to its outcrop area except for those parts of the formations that consist of unfractured, noncarbonate rock.

Recharge to the Conasauga, Copper Ridge, and Chepultepec aquifers occurs in northern Bibb, western Tuscaloosa, southern Jefferson, and western Shelby Counties (plate 1). The recharge area, covering approximately 50 to 55 square miles within the study area, is a series of complexly folded and faulted rocks (plate 1). The area is primarily wooded with a few acres of pastureland. Very little cultivated land is found in the area due to its rocky nature. Ground water in these aquifers is stored and transmitted in secondary pores, consisting of joints, fractures, and bedding planes that have been enlarged by solution. The Conasauga, Copper Ridge, and the Chepultepec are solutionchannel aquifers. The yields of a well in these aquifers depends on the number, size, and interconnection of the solution channels the well penetrates (Moffett, 1976).

A potentiometric surface for the aquifers is difficult to determine in these areas because of the complexities of the folds and faults in the formations. However, water movement in these aquifers generally follows the direction of the valleys on a regional basis. Locally, it follows the topography of the land. Springs commonly occur where the land surface is below the potentiometric surface of the aquifer. Fractures in the formations allow water to flow from the springs. Ground water discharges as surface runoff that may disappear into sinkholes or fractures somewhere downstream to become ground water once again.

The recharge area for the coker aquifer in the study area is in Bibb County with small areas in Hale and perry Counties (plate 1) and covers approximately 336 square miles. The recharge area for the Gordo aquifer is in 
northern Hale County, southern Bibb County, Perry County, and northern Dallas County; it covers approximately 322 square miles. Hydraulic interconnection between the Coker and Gordo Formations is sufficient, such that the formations are usually reported as the Tuscaloosa aquifer. The potentiometric surface of the Tuscaloosa is shown on plate 1. Regionally, the direction of ground-water flow in the Tuscaloosa aquifer and all other aquifers in the study area is to the southwest. Locally, the direction of flow is from hill tops towards the river valleys in the area.

The recharge area for the Eutaw aquifer is primarily in Hale, Perry, and northern Dallas Counties. This area covers approximately 837 square miles and consists largely of rolling sandhills, parts of which are wooded and parts cultivated farmland and pastureland.

The recharge area for the Ripley aquifer is along and just north of the Dallas-Wilcox county line in an area of about 116 square miles. The terrain is primarily pine-forested hills and cuestas with very little urban development.

The recharge areas for the Nanafalia and Tuscahoma aquifers are in southern Wilcox County. These aquifers alternate with relatively impermeable layers of chalk and clay. Together, they cover an area of about 300 square miles. Much of this area is wooded, but there are also many acres of pasture and farmland. These areas are partly rolling terrain with little change in elevation and partly highly eroded terrain with some relatively large elevation changes cutting through several formations as found in parts of wilcox County. These two units are major aquifers to the south of the study area.

The Tuscaloosa, Eutaw, and Ripley aquifers become artesian when they are confined by layers of relatively impermeable clay and chalk downdip from their recharge areas. These layers of clay and chalk restrict or prevent the vertical movement of water from one aquifer to the next.

Alluvial and terrace deposits overlie parts of the outcrop areas of the major aquifers. These deposits form relatively flat, permeable landscapes that impede runoff and as a result, probably increase recharge except where there are points of discharge of ground water to streams. Alluvial deposits overlie the major aquifers along the Black Warrior, Alabama, and Cahaba Rivers. Water moves downdip from areas of recharge, perpendicular to the potentiometric contour lines shown on plate 1 , to areas of natural discharge or areas of ground-water withdrawal.

\section{Natural Discharge and Ground-Water Withdrawals}

A large part of the ground water is discharged through seeps and springs to provide base (dry weather) flow of streams. This natural discharge is very evident in Bibb County where many springs flow more than $100 \mathrm{gal} / \mathrm{min}$. Many other springs and seeps are located in Dallas, Hale, Perry, and Wilcox Counties. Much of this flow is discharged into rivers and streams that are incised into the aquifers. Although many flowing artesian wells are in the study area, their effect on the water levels in the aquifers probably is insignificant. 
Most of the remainder of the ground water is discharged through wells at the larger pumping centers. The largest pumping center in the study area is the city of selma. The combined capacity of Selma's well field is more than $10 \mathrm{Mgal} / \mathrm{d}$ (million gallons per day). The average amount pumped from the wells in 1985 was about $4 \mathrm{Mgal} / \mathrm{d}$ (Selma Water Works, written commun., 1986). Water is withdrawn from both of the major aquifers (Tuscaloosa and Eutaw) in the area.

Other pumping centers in the study area and their estimated capacities are Green Pond, $0.418 \mathrm{Mgal} / \mathrm{d}$; West Blocton, $1.00 \mathrm{Mgal} / \mathrm{d}$; Centreville, 1.44 Mgal/d; Brent, 1.25 Mgal/d; Moundville, $0.835 \mathrm{Mgal} / \mathrm{d} ;$ Greensboro, $3.38 \mathrm{Mgal} / \mathrm{d}$; Marion, $3.00 \mathrm{Mgal} / \mathrm{d}$; Uniontown, $2.30 \mathrm{Mgal} / \mathrm{d}$; Orrville, $0.086 \mathrm{Mgal} / \mathrm{d} ;$ Camden, $1.08 \mathrm{Mgal} / \mathrm{d}$; Pine Apple, $0.137 \mathrm{Mgal} / \mathrm{d}$; Perry County, $0.202 \mathrm{Mga} 1 / \mathrm{d}$; North Dallas County, $0.648 \mathrm{Mgal} / \mathrm{d}$; Dallas County, $2.016 \mathrm{Mgal} / \mathrm{d} ;$ and Wilcox County, $0.144 \mathrm{Mgal} / \mathrm{d}$ (Alabama Department of Environmental Management, 1985 data files).

The remainder of the discharge is from wells used for domestic, stock, industrial, and irrigation purposes. The amount of water used for these purposes is estimated to be 4 to $8 \mathrm{Mgal} / \mathrm{d}$.

Total maximum withdrawals of ground water for all uses in the study area in 1985 are estimated to be about $20 \mathrm{Mgal} / \mathrm{d}$ based on an inventory of water users.

\section{Effects of Withdrawals from the Aquifers}

Large withdrawals of water from an aquifer result in a depression in the potentiometric surface of the aquifer. The areal extent and depth of the depression depends on the amount of water withdrawn and the water bearing capacity of the aquifer. The only significant depression in the study area is around Selma's well field where the Tuscaloosa and Eutaw aquifers are utilized. Other less extensive depressions probably occur around other pumping centers in the study area, but their effects would be localized.

\section{SUSCEPTIBILITY OF THE AQUIFERS TO LAND-SURFACE CONTAMINATION}

All of the areas of recharge for the major aquifers in the study area are susceptible to contamination from the land surface (plate 1). The majority of each recharge area in the study area is rural and consists of woodland, pastures, or farms. This reduces the possibility of contamination from an industrial source under the current land use. These areas are several miles from the major pumping centers and consist of sand hills and intermediate streams. The exception to this is the valley and Ridge province in northern Bibb County and the Black Prairie District in the central part of the study area.

The aquifers that are highly susceptible to contamination from the land surface are in Bibb and Dallas Counties. The towns of Green Pond, West Blocton, Brent, and Centreville in Bibb County obtain their water from springs and wells in aquifers in the limestone and dolomite formations in the area. These rocks have many faults and fractures that allow a much faster rate of 
ground-water flow compared to the rate of flow in a sand aquifer. In the area underlain by limestone and dolomite, some sinkholes exist (U.S. Geological Survey, 1977). Figure 4 outlines the areas within the study area where sinkholes exist or could occur in the future. These sinkholes commonly are in direct connection to the water table from the land surface. A contaminant released in the area of a sinkhole could quickly affect the quality of water in the aquifers in the area.

The towns of Brent and Centreville have their public water-supply wells in the same dolomite formations as Green Pond and West Blocton. The wells are about 100 to 300 feet deep. The area in the vicinity of the wells is covered by alluvial and terrace deposits near the Cahaba River and the sandy deposits of the Coker Formation in other areas. These formations are highly permeable and cause the aquifers to be highly susceptible to contamination from the land surface. Sinkholes are present near Centreville and make the area highly susceptible to land-surface contamination. A significant fact here is that the large metropolitan areas of neighboring Jefferson and Shelby counties lie in the Valley and Ridge province. The direction of ground-water movement is from metropolitan areas, down the valleys, toward Bibb county and toward the recharge area for the major aquifers in the area. This increases the possibility of a contaminant entering the aquifer system in northern Bibb County.

Other areas of high susceptibility to contamination occur where alluvial deposits overlie recharge areas for the major aquifers (fig. 4). These areas are relatively flat, which causes surface runoff to be much slower; thus, water has a longer period of time to seep into the ground. Normally, the alluvial plains are areas of ground-water discharge to the rivers and streams. However, if a large pumping center is on the alluvial plain, the decline of water levels in the aquifer caused by ground-water withdrawals could be sufficient to reverse the direction of ground-water flow--that is, streams then would recharge aquifers under the alluvial plain deposits.

An area of alluvial deposits overlies the Eutaw Formation outcrop northeast of selma's well field. Ground-water movement in this area is to the southwest. Withdrawals of water from the Selma well field has caused a significant cone of depression in the potentiometric surface of the Eutaw aquifer. An increase in the slope of the depression indicates an increase in the flow of water towards the center of the cone. A contaminant released in this area would almost certainly migrate towards the withdrawal point from the Eutaw aquifer in the Selma well field. The Tuscaloosa (Coker and Gordo Formations) aquifer, which Selma also uses for water supply is overlain by layers of clay that prevent or retard any vertical movement of water or contaminants into the aquifers in this area.

Water from remaining municipal water-supply wells in the study area are not in as much danger of contamination as the water in Bibb and Dallas Counties. All remaining wells are generally deeper than 300 to 400 feet. Within the overlying sediments are confining beds of clay and chalk that would prevent most land-surface contaminants from reaching the aquifer. 


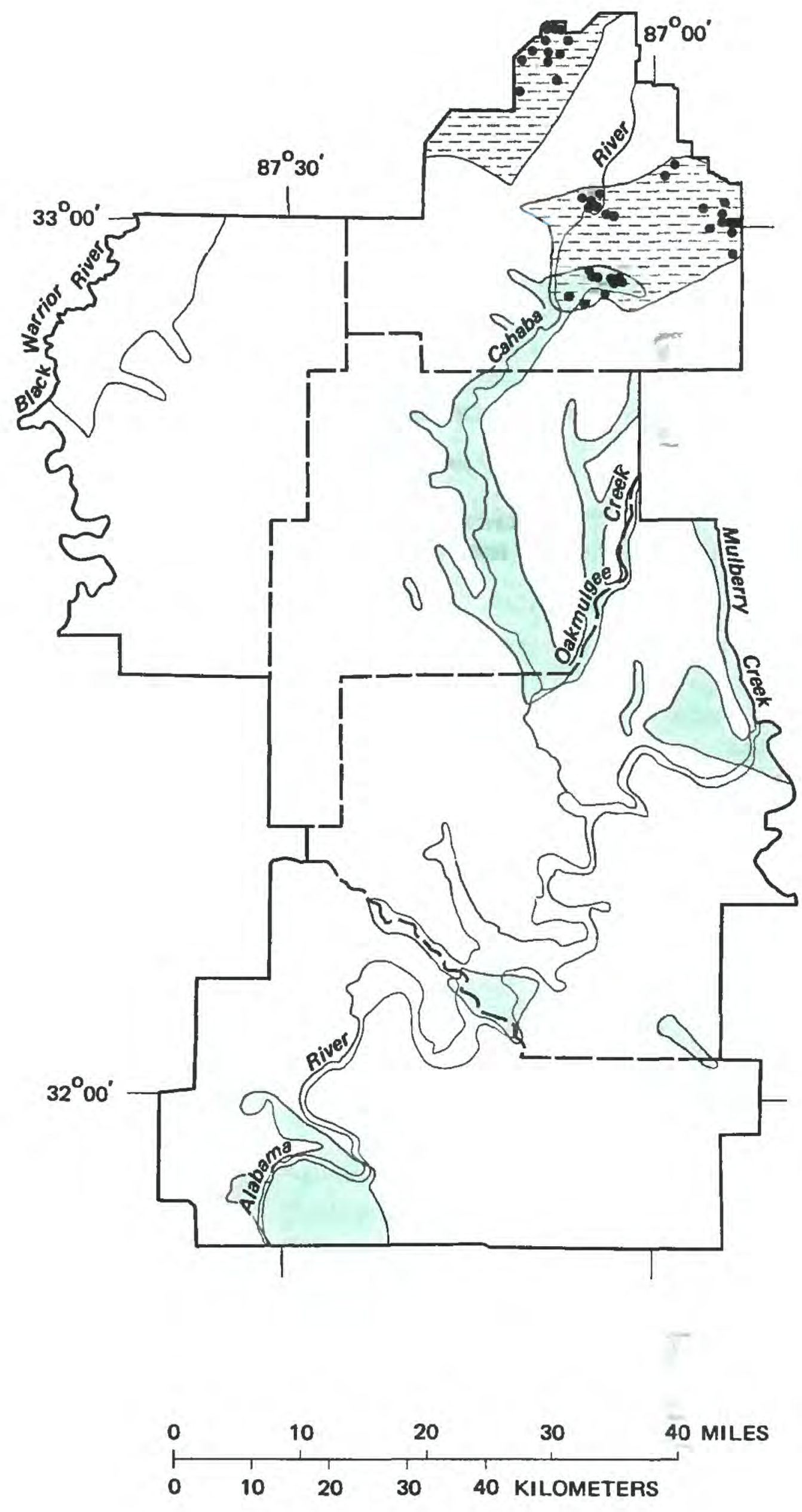

\section{EXPLANATION}

AREAS HIGHLY SUSCEPTIBLE TO LAND SURFACE CONTAMINATION OF GROUND WATER

E- Areas where sinkholes could occur in the future

Areas where alluvial and terrace deposits overlie recharge areas for major aquifers

- SINKHOLE

Figure 4.-- Areas highly susceptible to ground-water contamination. 


\section{SUMMARY AND CONCLUSIONS}

The counties that comprise the area of this study (Bibb, Dallas, Hale, Perry, and Wilcox) have abundant supplies of fresh ground water to meet present demands. There are seven major aquifers within Area 7 . Aquifers in the northern part of the study area are in Paleozoic limestone and dolomite formations. They are the conasauga Formation and the copper Ridge and Chepultepec Dolomites of the knox Group. The remaining aquifers in the central and southern part of Area 7 are of Cretaceous age. They are the Coker, Gordo, Eutaw, and Ripley aquifers.

Contamination of the major aquifers in the area is improbable because most of the recharge area for the primary aquifers consists of woodland, pasture, or farmland; few industrial areas are in the recharge area, except around Selma.

Downgradient from outcrop areas, the major aquifers in the study area are protected from surface contamination by relatively impermeable layers of clay and chalk.

The aquifers that are highly susceptible to contamination are in the limestone and dolomite formations in northern Bibb county. These formations contain solutionally enlarged joints, fractures, and caverns through which water or contaminants could rapidly pass to the water table. Sinkholes also occur in the recharge area of these formations and could provide a direct link for contaminants from the land surface to the water table. The large metropolitan areas in Jefferson and Shelby Counties, though outside the study area, are a possible source of contamination to these aquifers because the general direction of ground-water movement is from the metropolitan areas toward the withdrawal areas for these aquifers.

An area northeast of the Selma well field is also highly susceptible to contamination. The Eutaw Formation in this area is overlain by unsaturated permeable alluvium that could facilitate recharge to the aquifer from slowmoving streams.

Other alluvial and terrace deposits along major streams in the study area are also considered highly susceptible to land-surface contamination. Pumping centers in these areas could lower water levels in aquifers that are in hydraulic connection with the streams to levels that are below those of the streams. As a result, water in streams would recharge the alluvial and terrace deposits. 
Adams, G.I., Butts, C., Stevenson, L.W., and Cooke, C.W., 1926, Geologic map of Alabama: Geological Survey of Alabama Special Map 7.

Alabama Department of Economic and Community Affairs, 1984, Alabama County Data Book: 92 p.

Carlston, C.W., 1944, Ground-water resources of the Cretaceous area of Alabama: Geological Survey of Alabama Special Report 18, 203 p.

Causey, L.V., Willmon, J.R., and Ellard, J.S., 1978, water availability in Bibb County, Alabama: Geological Survey of Alabama Map 144, 16 p.

Copeland, C.W., 1968, Geology of the Alabama Coastal Plain--Guidebook for 60th annual meeting of American State Geologists May 6-8: Geological Survey of Alabama Circular 47,97 p.

Davis, M.E., 1980, Generalized geologic map and southern extent of major use of ground water from principal aquifers in Alabama: 1 sheet.

Davis, M.E., Sanford, R.H., Jr., and Jefferson, P.0., 1975, water availability and geology of Hale County, Alabama: Geological Survey of Alabama Map $136,51 \mathrm{p}$.

Geological Survey of Alabama, 1969, Mineral, water, and energy resources of Wilcox County, Alabama: Geological Survey of Alabama Information Series 40,49 p.

Kidd, J.T., 1979, Areal geology of Jefferson County, Alabama: Geological Survey of Alabama Atlas 15, 89 p.

Kidd, R.E., 1976, Tuscaloosa group aquifers in Barksdale, H. C., Moore, J.D., and others, water content and potential yield of significant aquifers in Alabama: Geological Survey of Alabama open-file report, 449 p.

LaMoreaux, P.E., and Toulmin, L.D., 1959, Geology and ground-water resources of Wilcox County, Alabama: Geological Survey of Alabama County Report 4, 280 p.

Moffett, T.B., 1976, Major aquifers of the Valley and Ridge Providence, in Barksdale, H.C. and others, Water content and potential yield of significant aquifers in Alabama: Geological Survey of Alabama open-file report, 449 p.

Monroe, w.H., 1941, Notes on deposits of Selma and Ripley age in Alabama: Geological Survey of Alabama Bulletin 48, 150 p.

Moore, J.D., 1976, The physical setting, in Barksdale, H.C. and others, Water content and potential yield of significant aquifers in Alabama: Geological Survey of Alabama open-file report, 449 p. 
National Oceanic and Atmospheric Administration, 1985, Alabama precipitation yearly normals 1951-80: Birmingham, River Forecast office.

Reed, P.C., 1972, Geology of Perry County, Alabama: Geological Survey of Alabama Map 118, 13 p.

Reed, P.C., Willmon, J.R., and Jefferson, P.O., 1972, water availability in Perry County, Alabama: Geological Survey of Alabama Map 127, 42 p.

Sapp, D.C., and Emplaincourt, Jacques, 1975, Physiographic regions of Alabama: Geological Survey of Alabama Map 168, 1 sheet.

Scott, J.C., Golden, H.G., and Newton, J.G., 1981, Geology and water availability of Dallas County, Alabama: Geological Survey of Alabama Map 180, 94 p.

Szabo, M.W., Mirza, A.B., Rheams, L.J., and Clarke, O.M., Jr., 1979, Engineering geology of Jefferson County, Alabama: Geological Survey of Alabama Atlas 14, 77 p.

U.S. Department of Commerce, 1984, Local population estimates: Bureau of Census Series P-26, No. 82-1-SC, 14 p.

U.S. Environmental Protection Agency, 1984, A ground-water protection strategy for the Environmental Protection Agency, 56 p.

U.S. Geological Survey, 1977, Areas in which sinkholes occurred or can occur in counties in Alabama: U.S. Geological Survey Open-File Maps.

Williams, J.S., DeJarnette, S.S., and Planert, Michael, 1986a, Potentiometricsurface and water-use map of the Tuscaloosa aquifer in Alabama, fall 1982: U.S. Geological Survey Water-Resources Investigations Report 85-4174, I sheet.

---1986b, Potentiometric-surface, ground-water withdrawals and recharge areas for the Eutaw aquifer in Alabama, fall 1982: U.S. Geological survey Water-Resources Investigations Report 86-4121, 1 sheet.

---1986c, Potentiometric-surface, ground-water withdrawals and recharge areas for the Lisbon aquifer in Alabama, fall 1982: U.S. Geological Survey Water-Resources Investigations Report 86-4120, 1 sheet.

Williams, J.S., Planert, Michael, and DeJarnette, S.S., 1986, Potentiometricsurface, ground-water withdrawals and recharge areas for the providenceRipley aquifer in Alabama, fall 1982: U.S. Geological Survey WaterResources Investigations Report 86-4118, I sheet. 
NOTE: Well numbers correspond to those shown on plate 1.

Geographic coordinate number: Lat (DDMMSS) Long (DDMMSS).

Depth of well and water level: Depth of well given in feet; reported water levels are in feet above ( - ) or below land surface; measured water levels are in feet and tenths.

Well diameter: Casing diameter in inches.

Water-bearing unit: Cc, Conasauga Formation, $\infty c c u$, Copper Ridge Dolomite and chepultepec Dolomite undifferentiated, Kc, Coker Formation; Kg, Gordo Formation; Ke, Eutaw Formation; Kr, Ripley Formation.

Altitude of land surface: Altitudes given in feet above sea level, from topographic map or determined by aneroid barometer.

Method of lift: S, submergible; T, turbine; F, flowing.

Use of well: $N$, none; $P$, public water supply.

\begin{tabular}{|c|c|c|c|c|c|c|c|c|c|c|c|c|}
\hline 1 & 3314000870740 & $\begin{array}{l}\text { Green Pond } \\
\text { Water } \\
\text { system }\end{array}$ & $\begin{array}{l}\text { Southern } \\
\text { well } \\
\text { Supply Co. } \\
1965\end{array}$ & 240 & 6 & Cc & 580 & 106 & $6 / 01 / 66$ & $\mathbf{T}$ & $\mathbf{P}$ & $\begin{array}{l}\text { Casing: } 6 \text { in. } \\
\text { from surface to } \\
239 \mathrm{ft} \text {; none } \\
\text { below. Supplies } \\
\text { community of Green } \\
\text { Pond. Reported } \\
\text { drawdown } 11 \mathrm{ft} \\
\text { after } 40 \text { days } \\
\text { pumping } 170 \\
\text { gal/min in } 1966 .\end{array}$ \\
\hline 2 & 3309460870849 & $\begin{array}{l}\text { Green Pond } \\
\text { water } \\
\text { System }\end{array}$ & & spring & & œccu & 460 & & & $\boldsymbol{F}$ & $\mathbf{P}$ & \\
\hline 3 & 3305100871436 & $\begin{array}{l}\text { West Blocton } \\
\text { Water Works }\end{array}$ & & spring & • & $\infty \operatorname{ccc} u$ & 335 & & & $\boldsymbol{F}$ & $\mathbf{P}$ & $\begin{array}{l}\text { Known as williams } \\
\text { Spring. Estimated } \\
\text { flow } 750 \text { gal/min } \\
\text { on } 10 / 25 / 67 \text {. } \\
\text { Reported } 1 \text { y pumped } \\
\text { about } 3.000 \\
\text { gal/min during } \\
\text { test in } 1967 \text {. }\end{array}$ \\
\hline 4 & 3256210870444 & $\begin{array}{l}\text { Centreville } \\
\text { Water S Sewe }\end{array}$ & & 358 & & œccu & 275 & & & & $\mathbf{N}$ & \\
\hline 5 & 3256360870536 & $\begin{array}{l}\text { Centreville } \\
\text { Water and } \\
\text { Sewer }\end{array}$ & $\begin{array}{l}\text { H.W. } \\
\text { Peerson } \\
\text { Supply Co. } \\
1962\end{array}$ & 110 & 6 & occcu & 260 & 16 & 1962 & $\mathbf{T}$ & $\mathbf{P}$ & $\begin{array}{l}\text { Casing: } 6 \text { in. } \\
\text { from surface to } \\
78 \text { ft; none below. } \\
\text { Reported drawdown } \\
70 \text { ft after } 24 \\
\text { hrs pumping } 180 \\
\text { gal } / \mathrm{m} \text { in in } 1962 \text {. }\end{array}$ \\
\hline 6 & 3256130870512 & $\begin{array}{l}\text { Centreville } \\
\text { Water and } \\
\text { Sewer }\end{array}$ & $\begin{array}{l}\text { Acme } \\
\text { Drilling } \\
\text { Co. } \\
1962\end{array}$ & 119 & 8 & œccu & 252 & 23 & 1963 & $T$ & $\mathbf{P}$ & $\begin{array}{l}\text { Casing: } 8 \mathrm{in} \text {. } \\
\text { from surface to } \\
101 \mathrm{ft} \text { none } \\
\text { below. Reported } \\
\text { drawdown } 35 \mathrm{ft} \\
\text { after } 8 \mathrm{hrs} \\
\text { pumping } 343 \mathrm{gal} / \\
\text { min in } 1963 .\end{array}$ \\
\hline 7 & 3258200871008 & $\begin{array}{l}\text { Brent } \\
\text { Utilities } \\
\text { Board }\end{array}$ & $\begin{array}{l}\text { Layne- } \\
\text { Central } \\
\text { Co. } \\
1971\end{array}$ & 600 & 6 & $\infty c c u$ & 280 & & & & $\mathbf{N}$ & $\begin{array}{l}\text { Casing to } 60 \mathrm{ft} \text {; } \\
\text { none below. }\end{array}$ \\
\hline 8 & 3257250871027 & $\begin{array}{l}\text { Brent } \\
\text { Utilities } \\
\text { Board }\end{array}$ & $\begin{array}{l}\text { Graves } \\
\text { Well } \\
\text { Drilling } \\
1971\end{array}$ & 500 & 6 & occu & 295 & 90 & $7-87$ & $\mathbf{T}$ & $\mathbf{P}$ & $\begin{array}{l}\text { Casing to } 56 \mathrm{ft} \text {; } \\
\text { none below. } \\
\text { Repoited pump } \\
\text { capacity } 133 \\
\text { gal/min. }\end{array}$ \\
\hline 9 & 3256310871032 & $\begin{array}{l}\text { Brent } \\
\text { Wtilities } \\
\text { Board }\end{array}$ & $\begin{array}{l}\text { Graves } \\
\text { Well } \\
\text { Drilitng } \\
1971\end{array}$ & 315 & 12 & occcu & 255 & 38 & $7-87$ & $\mathrm{~T}$ & $\mathbf{P}$ & $\begin{array}{l}\text { Casing to } 95 \mathrm{ft} \text {; } \\
\text { none below. } \\
\text { Reported pump } \\
\text { capacity } 500 \\
\text { gal/min. }\end{array}$ \\
\hline
\end{tabular}


Table 1.--Records of public water-supply we11s and springs in the study area--Cont Inued

\begin{tabular}{|c|c|c|c|c|c|c|c|c|c|c|c|c|}
\hline $\begin{array}{c}\text { Well } \\
\text { number }\end{array}$ & $\begin{array}{l}\text { Geographic } \\
\text { coordinate } \\
\text { number }\end{array}$ & $\begin{array}{l}\text { Well } 1 \\
\text { owner }\end{array}$ & $\begin{array}{l}\text { Driller } \\
\text { and year } \\
\text { drilled }\end{array}$ & $\begin{array}{l}\text { We11 } \\
\text { depth } \\
\text { (feet) }\end{array}$ & $\begin{array}{c}\text { We11 } \\
\text { diam. } \\
\text { (Inches) }\end{array}$ & $\begin{array}{l}\text { Water } \\
\text { bearing } \\
\text { unit }\end{array}$ & $\begin{array}{l}\text { Altitude } \\
\text { of land } \\
\text { surface } s\end{array}$ & $\begin{array}{l}\text { Water level } \\
\text { above }(+) \text { or } \\
\text { below Land } \\
\text { Surface Datum }\end{array}$ & $\begin{array}{l}\text { Date of } \\
\text { measure- } \\
\text { ment }\end{array}$ & $\begin{array}{l}\text { Method } \\
\text { of } \\
11 f t\end{array}$ & $\begin{array}{l}\text { Use } \\
\text { of } \\
\text { well }\end{array}$ & Remarks \\
\hline 10 & 3242110873533 & $\begin{array}{l}\text { Greensboro } \\
\text { Utilities } \\
\text { Dept. }\end{array}$ & $\begin{array}{l}\text { Layne- } \\
\text { Central } \\
\text { Co. } \\
1957\end{array}$ & 706 & 18,10 & $\mathbf{R g}$ & 287 & 117 & 1957 & $\mathbf{T}$ & $\mathbf{P}$ & $\begin{array}{l}\text { Casing: } 18 \text { in. } \\
\text { from surface to } \\
621 \mathrm{ft} \text {, } 10 \mathrm{in} \text {. } \\
\text { fram } 537 \text { to } 635.5 \\
\text { ft, } 10 \text { in, screen } \\
\text { between } 635.5 \text { and } \\
705.5 \mathrm{ft}, 12 \text { in. } \\
\text { gravel wall } \mathrm{frcan} \\
606 \text { to } 706 \mathrm{ft} \text {. } \\
\text { Drawdown } 17 \mathrm{ft} \\
\text { after } 8 \mathrm{hrs} \text { pump- } \\
\text { ing } 618 \mathrm{gal} / \mathrm{min} \\
\text { in } 1957 \text {. }\end{array}$ \\
\hline
\end{tabular}

\begin{tabular}{|c|c|c|c|c|c|c|c|c|c|c|c|c|}
\hline 11 & 3242100873540 & $\begin{array}{l}\text { Greensboro } \\
\text { Ut ilities } \\
\text { Dept. }\end{array}$ & $\begin{array}{l}\text { Layne- } \\
\text { Central } \\
\text { Co. } \\
1929\end{array}$ & 390 & 18, & Re & 258 & 84 & 1929 & $\mathbf{T}$ & $\mathbf{N}$ & $\begin{array}{l}\text { Casing: } 18 \text { in. } \\
\text { fram surface to } \\
100 \mathrm{ft} \text {, } 8 \text { in. } \mathrm{frcm} \\
\text { surface to } 370 \mathrm{ft} \text {; } \\
8 \text { in. screen } \\
\text { between } 370 \text { and } \\
390 \mathrm{ft} \text {. }\end{array}$ \\
\hline 12 & 3242160873523 & $\begin{array}{l}\text { Greensboro } \\
\text { utilities } \\
\text { Dept. }\end{array}$ & $\begin{array}{l}\text { Layne- } \\
\text { Central } \\
\text { Co. } \\
1950\end{array}$ & 710 & 16,8 & $\mathbf{R g}$ & 259 & 89.4 & 1952 & $\mathbf{T}$ & $\mathbf{P}$ & $\begin{array}{l}\text { Casing: } 16 \text { in. } f r a m \\
\text { surface to } 630 \mathrm{ft} \text {; } \\
\text { B in. screen } \\
\text { between } 630 \text { and } 700 \\
\mathrm{ft}, 8 \text { in. fran } 700 \\
\text { to } 710 \mathrm{ft} \text {. Draw- } \\
\text { down } 23 \mathrm{ft} \text { after } 8 \\
\mathrm{hrs} \text { pumping } 545 \\
\text { gal/min in } 1950 \text {. }\end{array}$ \\
\hline 13 & 3257150873709 & $\begin{array}{l}\text { Moundiville } \\
\text { Water Works }\end{array}$ & $\begin{array}{l}\text { Graves } \\
\text { We11 } \\
\text { Dri11ing } \\
1972\end{array}$ & 233 & 16 & Kg & 180 & 58 & $5-87$ & $\mathbf{T}$ & $\mathbf{p}$ & $\begin{array}{l}\text { Reported pump } \\
\text { capacity } 500 \\
\text { gal/min. }\end{array}$ \\
\hline 14 & 3257110873627 & $\begin{array}{l}\text { Moundville } \\
\text { Water Works }\end{array}$ & $\begin{array}{l}\text { Graves } \\
\text { Well } \\
\text { Dri111ng } \\
1981\end{array}$ & 240 & 16 & $\mathbf{R g}$ & 200 & 26 & $5-87$ & $\mathbf{T}$ & p & $\begin{array}{l}\text { Reported pump } \\
\text { capacity } 500 \\
\text { gal/min. }\end{array}$ \\
\hline 15 & 3248120871703 & $\begin{array}{l}\text { Perry Co. } \\
\text { Water } \\
\text { Fire }\end{array}$ & $\begin{array}{l}\text { Graves } \\
\text { Well } \\
\text { Dril11ng } \\
1981\end{array}$ & 600 & B & Re & 260 & 55 & $5-25-87$ & $\mathbf{T}$ & $P$ & $\begin{array}{l}\text { Casing: } 8 \text { in, } \\
\text { fram surface to } \\
494 \mathrm{ft}, 4 \text { in. } \\
\text { screen from } 494 \text { to } \\
537 \mathrm{ft}, 106 \mathrm{ft} \\
\text { of lap pipe. }\end{array}$ \\
\hline 16 & 3238090872026 & $\begin{array}{l}\text { Marion } \\
\text { Water Dept. }\end{array}$ & $\begin{array}{l}\text { Layne- } \\
\text { Central } \\
\text { Co. } \\
1970\end{array}$ & 674 & 16,10 & $\mathrm{~kg}$ & 360 & & & $\mathbf{T}$ & $\mathbf{p}$ & $\begin{array}{l}\text { Casing: } 16 \text { in. } \\
\text { from surface to } \\
405 \mathrm{ft} \text {, } 10 \text { in. } \\
\text { fram } 325 \text { to } 405 \\
\text { ft, } 10 \text { in. screen } \\
\text { between } 410 \text { and } \\
450 \mathrm{ft} \text {. and } \\
\text { between } 560 \text { and } \\
600 \mathrm{ft} \text {. }\end{array}$ \\
\hline 17 & 3237160871933 & $\begin{array}{l}\text { Marion } \\
\text { Water Dept. }\end{array}$ & $\begin{array}{l}\text { Layne- } \\
\text { Central } \\
1963\end{array}$ & 391 & 16,10 & $\mathrm{Ke}$ & 315 & 163.42 & $10-21-86$ & $\mathbf{T}$ & $\mathbf{P}$ & $\begin{array}{l}\text { Casing: } 16 \text { in. fram } \\
\text { surface to } 292 \mathrm{ft} \text {; } \\
297 \mathrm{ft} \text {; } 10 \text { in. } \\
\text { screen from } 297 \text { to } \\
347 \mathrm{ft} \text {. }\end{array}$ \\
\hline 18 & 3237560872003 & $\begin{array}{l}\text { Marion } \\
\text { Water Dept. }\end{array}$ & $\begin{array}{l}\text { Layne- } \\
\text { Central } \\
\text { Co. }\end{array}$ & 516 & 18 & Kg & 350 & & & $\mathbf{T}$ & P & $\begin{array}{l}\text { Casing } 513 \mathrm{ft} . \\
\text { Reported pump } \\
\text { capacity } 800 \\
\text { gal/min. }\end{array}$ \\
\hline
\end{tabular}


Table 1.--Records of public water-supply wells and springs in the study area--Continued

\begin{tabular}{|c|c|c|c|c|c|c|c|c|c|c|c|c|c|}
\hline $\begin{array}{c}\text { Well } \\
\text { number }\end{array}$ & $\begin{array}{c}\text { Geographic } \\
\text { coordinate } \\
\text { number }\end{array}$ & $\begin{array}{l}\text { Well } \\
\text { owner }\end{array}$ & $\begin{array}{l}\text { Driller } \\
\text { and year } \\
\text { drilled } \\
\text { driled }\end{array}$ & $\begin{array}{l}\text { Well } \\
\text { depth } \\
\text { (feet) }\end{array}$ & $\begin{array}{c}\text { Well } \\
\text { diam. } \\
\text { (1nches) }\end{array}$ & $\begin{array}{l}\text { Water } \\
\text { bearing } \\
\text { unit }\end{array}$ & $\begin{array}{l}\text { Altitude } \\
\text { of land } \\
\text { surf ace }\end{array}$ & $\begin{array}{l}\text { Water } \\
\text { above } \\
\text { below } \\
\text { surface }\end{array}$ & $\begin{array}{l}\text { level } \\
(+) \text { or } \\
\text { Land } \\
\text { Datum }\end{array}$ & $\begin{array}{l}\text { Date of } \\
\text { measure- } \\
\text { ment }\end{array}$ & $\begin{array}{l}\text { Method } \\
\text { of } \\
\text { lift }\end{array}$ & $\begin{array}{c}\text { Use } \\
\text { of } \\
\text { well } \\
\text { seses }\end{array}$ & $\begin{array}{l}\text { Remarks } \\
\cdot\end{array}$ \\
\hline 19 & 3226530873054 & $\begin{array}{l}\text { Uniontown } \\
\text { Utilities } \\
\text { Board }\end{array}$ & $\begin{array}{l}\text { Layne- } \\
\text { Central } \\
\text { Co. } \\
1954\end{array}$ & 1,050 & 16,6 & Ke & 263 & 95 & & $7-87$ & $T$ & P & $\begin{array}{l}\text { Casing: } 16 \text { in. } \\
\text { from surface to } \\
850 \mathrm{ft} \text {; } 6 \text { in. fram } \\
770 \text { to } 855 \mathrm{ft} \text {; } \\
\text { screen from } 855 \text { to } \\
875 \mathrm{ft} \text {; } 6 \text { in. } \\
\text { casing from } 875 \text { to } \\
895 \mathrm{ft} \text {; screen } \\
\text { from } 895 \text { to } 915 \\
\mathrm{ft} \text {. }\end{array}$ \\
\hline 20 & 3227020873126 & $\begin{array}{l}\text { Uniontown } \\
\text { Utilities } \\
\text { Board }\end{array}$ & $\begin{array}{l}\text { Carloss } \\
\text { Well } \\
\text { Supply } \\
\text { Co. } \\
1970\end{array}$ & 1,050 & 16,8 & Ke & 287 & 148 & & $7-87$ & $T$ & $\mathbf{P}$ & $\begin{array}{l}\text { Casing: } 16 \text { in. } \\
\text { from surface to } \\
850 \mathrm{ft}, 8 \mathrm{in} \text {. fram } \\
768 \text { to } 855 \mathrm{ft} \text {, } \\
\text { screen from } 855 \text { to } \\
935 \mathrm{ft} \text {. }\end{array}$ \\
\hline 21 & 3239330865526 & $\begin{array}{l}\text { Planters- } \\
\text { ville } \\
\text { Water } \\
\text { System }\end{array}$ & $\begin{array}{l}\text { Acme } \\
\text { Drilling } \\
\text { Co. } \\
1966\end{array}$ & 527 & 6,4 & Kc & 256 & 20 & & 1966 & $\mathbf{T}$ & $\mathbf{p}$ & $\begin{array}{l}\text { Casing: } 6 \text { in. fram } \\
\text { surface to } 470 \mathrm{ft} \text {; } \\
4 \text { in. from } 459 \text { to } \\
527 \mathrm{ft}, 26 \mathrm{ft} \text { of } \\
4 \text { in. screen be- } \\
\text { tween } 472 \text { and } 521 \\
\mathrm{ft} \text {. Reported draw- } \\
\text { down } 24 \mathrm{ft} \text { after } \\
4 \mathrm{hrs} \text { pumplng } 118 \\
\text { gal/min in } 1965 \text {. }\end{array}$ \\
\hline 22 & 3227200870001 & $\begin{array}{l}\text { North } \\
\text { Dallas Co. } \\
\text { Water } \\
\text { Fire }\end{array}$ & $\begin{array}{l}\text { Brady } \\
\text { Well } \\
\text { Supply } \\
\text { Co. } \\
1961\end{array}$ & 610 & 4,3 & $\mathrm{~kg}$ & 214 & 64 & & 1961 & $\mathbf{T}$ & $\mathbf{P}$ & $\begin{array}{l}\text { Casing: } 4 \text { in. from } \\
\text { surface to } 132 \mathrm{ft} \text {; } \\
3 \text { in. from } 120 \text { to } \\
610 \mathrm{ft}, 3 \text { in. } \\
\text { screen between } \\
582 \text { and } 610 \mathrm{ft} \text {. } \\
\text { Reported drawdown } \\
21 \mathrm{ft} \text { after } 20 \\
\mathrm{hrs} \text { pumping } 40 \\
\text { gal/min in } 1961 \text {. }\end{array}$ \\
\hline 23 & 3227200870000 & $\begin{array}{l}\text { North } \\
\text { Dallas Co. } \\
\text { Water } \\
\text { Fire }\end{array}$ & $\begin{array}{l}\text { Layne- } \\
\text { Central } \\
\text { Co. } \\
1962\end{array}$ & 628 & 12,6 & $\mathbf{k g}$ & 214 & 55 & & 1962 & $\mathbf{T}$ & P & $\begin{array}{l}\text { Casing: } 12 \mathrm{in} \text {. } \\
\mathrm{frcm} \text { surface to } \\
560 \mathrm{ft}, 6 \mathrm{in} \text {. from } \\
497 \mathrm{to} 564 \mathrm{ft}, 40 \\
\mathrm{ft} \text { of } 6 \mathrm{in} \text {. screen } \\
\text { between } 564 \mathrm{ft} \text { and } \\
628 \mathrm{ft} \text {. Reported } \\
\text { drawdown } 14 \mathrm{ft} \\
\text { after } 8 \mathrm{hrs} \mathrm{pump}- \\
\text { ing } 250 \mathrm{gal} / \mathrm{min} \\
\text { ln } 1962 \text {. }\end{array}$ \\
\hline 24 & 3218230871440 & $\begin{array}{l}\text { Orrville } \\
\text { Water } \\
\text { Dept. }\end{array}$ & $\begin{array}{l}\text { W.J. } \\
\text { Bozeman } \\
1960\end{array}$ & 546 & 8,6 & $\mathrm{Ke}$ & 192 & 54 & & 1959 & $T$ & $\mathbf{P}$ & $\begin{array}{l}\text { Casing: } 8 \text { in. from } \\
\text { surface to } 518 \mathrm{ft} \text {; } \\
6 \mathrm{in} \text {. from } 518 \text { to } \\
521 \mathrm{ft} ; 6 \mathrm{in} \text {. } \\
\text { screen from } 521 \text { to } \\
546 \mathrm{ft} \text {. Reported } \\
\text { drawdown } 94 \mathrm{ft} \\
\text { after } 10 \mathrm{hrs} \text { pump- } \\
\text { ing } 100 \mathrm{gal} / \mathrm{min} \\
\text { in } 1959 \text {. }\end{array}$ \\
\hline 25 & 3224390870051 & $\begin{array}{l}\text { Selma } \\
\text { Water } \\
\text { Works } \\
\text { Sewer }\end{array}$ & $\begin{array}{l}\text { Layne- } \\
\text { Central } \\
\text { Co. }\end{array}$ & 963 & 24,16 & Kc & 125 & +60 & . & 1979 & $\mathbf{T}$ & $\mathbf{p}$ & $\begin{array}{l}\text { Casing: } 24 \text { in. } \\
\text { at surface, } 16 \text { in. } \\
\text { from surface to } \\
850 \mathrm{ft}, 8 \text { in. } \\
\text { screen from } 850 \text { to } \\
875 \mathrm{ft} \text {, casing } 875 \\
\text { to } 896 \mathrm{ft} \text {; } 8 \mathrm{creen} \\
896 \mathrm{to} 916 \mathrm{ft} \text {, } \\
\text { casing } 916 \mathrm{to} 928 \\
\mathrm{ft} \text { screen } 928 \text { to } \\
948 \mathrm{ft} \text {; } 15 \mathrm{ft} \text { of } \\
6 \text { in. pipe on } \\
\text { bottom. }\end{array}$ \\
\hline
\end{tabular}




\begin{tabular}{|c|c|c|c|c|c|c|c|c|c|c|c|c|c|}
\hline $\begin{array}{c}\text { We } 11 \\
\text { nuniber } \\
z= \pm=z=\end{array}$ & $\begin{array}{c}\text { Geographic } \\
\text { coordinate } \\
\text { number } \\
\Rightarrow=x==x=x=x=x\end{array}$ & $\begin{array}{l}\text { Well } \\
\text { Owner }\end{array}$ & $\begin{array}{l}\text { Driller } \\
\text { and year } \\
\text { drilled } \\
=\equiv=\equiv=m=\equiv=m\end{array}$ & $\begin{array}{l}\text { Well } \\
\text { depth } \\
\text { (feet) }\end{array}$ & $\begin{array}{c}\text { Well } \\
\text { diam. } \\
\text { (1 nches) }\end{array}$ & $\begin{array}{l}\text { Water } \\
\text { bearing } \\
\text { unit } \\
=x=x=x=x\end{array}$ & $\begin{array}{l}\text { Alt } 1 \\
\text { of } 1 \\
\text { surf } \\
==2==\end{array}$ & $\begin{array}{l}\text { Itude } \\
\text { land } \\
\text { face S } \\
= \pm=x=2\end{array}$ & 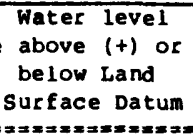 & $\begin{array}{l}\text { Date of } \\
\text { measure- } \\
\text { ment } \\
x=x=x=m=\end{array}$ & $\begin{array}{l}\text { Method } \\
\text { of } \\
11 \mathrm{ft} \\
0=x=x=x\end{array}$ & $\begin{array}{c}\text { Use } \\
\text { of } \\
\text { wel } 1 \\
x== \pm=0\end{array}$ & 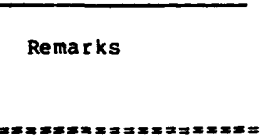 \\
\hline $\begin{array}{c}z \geq x=z= \\
26\end{array}$ & 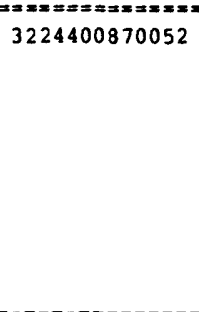 & $\begin{array}{l}=x=x=2=0=x= \\
\text { Selma } \\
\text { Water } \\
\text { Works } \\
\text { Sewer }\end{array}$ & $\begin{array}{l}\Rightarrow=x=1=x=0= \\
\text { Layne- } \\
\text { Central } \\
\text { Co. } \\
1955\end{array}$ & $\begin{array}{c}=x=x=m \\
434\end{array}$ & $\begin{array}{c}x=x=x=x= \\
24,12\end{array}$ & $\begin{array}{l}=x=x=x== \\
\text { Ke }\end{array}$ & $\begin{array}{r}x=x= \\
127\end{array}$ & $\begin{array}{l}= \pm x=2 x \\
7\end{array}$ & $\begin{aligned}: x \geq x=x=x=x=x=x= \\
\\
28.9 \\
36.11\end{aligned}$ & $\begin{array}{l}=x=x=x= \\
10-11-62 \\
10-28-86\end{array}$ & $\begin{array}{c}m=x=x=x \\
T\end{array}$ & $\begin{array}{c}=\Rightarrow=x=x \\
P\end{array}$ & 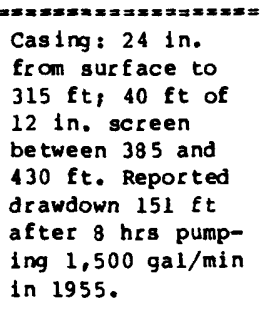 \\
\hline 27 & 3224400870048 & $\begin{array}{l}\text { Selma } \\
\text { Water } \\
\text { Works } \\
\text { Sewer }\end{array}$ & $\begin{array}{l}\text { Layne- } \\
\text { Central } \\
\text { Co. } \\
1963\end{array}$ & 711 & 24,12 & $\mathbf{K g}$ & 129 & $\begin{array}{l}1 \\
1\end{array}$ & +17 & 1963 & $\mathbf{T}$ & $\mathbf{P}$ & $\begin{array}{l}\text { Casing: } 24 \text { in. } \\
\text { from surface to } \\
570 \mathrm{ft} 12 \mathrm{in} \text {. } \\
\text { from } 490 \mathrm{ft} \text { to } 575 \\
\mathrm{ft} 12 \mathrm{in} \text {. screen } \\
\text { and casing between } \\
575 \text { and } 711 \mathrm{ft} \text {. } \\
\text { Reported dr awdown } \\
85 \mathrm{ft} \text { after } 8 \mathrm{hrs} \\
\text { pumping } 1,520 \\
\text { gal/min for } 24 \mathrm{hrs} \\
\text { in } 1963 \text {. }\end{array}$ \\
\hline 28 & 3224520870102 & $\begin{array}{l}\text { Selma } \\
\text { Water } \\
\text { Works } \\
\text { Sewer }\end{array}$ & $\begin{array}{l}\text { Layne- } \\
\text { Central } \\
\text { Co. } \\
1949\end{array}$ & 412 & 24,12 & Ke & 126 & & 26 & 1949 & $\mathbf{T}$ & $\mathbf{p}$ & $\begin{array}{l}\text { Casing: } 24 \text { in. } \\
\text { from surface to } \\
266 \mathrm{ft}, 12 \mathrm{in} \text {. } \\
\text { from } 209 \text { to } 412 \\
\mathrm{ft} 60 \mathrm{ft} \text { of } 12 \\
\text { in. screen between } \\
274 \text { and } 412 \mathrm{ft} \text {. } \\
\text { Reported dr awdown } \\
\text { log ft after } 24 \\
\mathrm{hrs} \text { pumping } 1,500 \\
\text { gal/min in } 1949 \text {. }\end{array}$ \\
\hline 29 & 3224220870020 & $\begin{array}{l}\text { Selma } \\
\text { Water } \\
\text { Works } \\
\text { Sewer }\end{array}$ & $\begin{array}{l}\text { Layne- } \\
\text { Central } \\
\text { Co. }\end{array}$ & 695 & 32,24 & Kg & 120 & 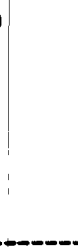 & +15 & 1987 & $\mathbf{T}$ & $\mathbf{P}$ & $\begin{array}{l}\text { Casing: } 32 \mathrm{in} \text {. } \\
\text { from surface to } 30 \\
\mathrm{ft} 24 \text { in. fron } \\
\text { surface to } 550 \mathrm{ft} \text {; } \\
12 \mathrm{in,} \mathrm{screen} \mathrm{from} \\
550 \mathrm{ft} \text { to } 680 \mathrm{ft} \text {; } \\
6 \mathrm{in} \text {. pipe from } \\
680 \mathrm{ft} \text { to } 695 \mathrm{ft} \text {. }\end{array}$ \\
\hline 30 & 3224120870026 & $\begin{array}{l}\text { Selma } \\
\text { Water } \\
\text { Works } \\
\text { Sewer }\end{array}$ & $\begin{array}{l}\text { Layne- } \\
\text { Central } \\
\text { Co. } \\
1944\end{array}$ & 429 & 24,12 & Ke & 120 & | & & & $\mathbf{T}$ & P & $\begin{array}{l}\text { Casing: } 24 \text { in. } \\
\text { from surface to } \\
340 \mathrm{ft}, 12 \mathrm{in} \text {. } \\
\text { from } 277 \text { to } 345 \\
\text { ft; } 12 \text { in. screen } \\
\text { from } 345 \text { to } 425 \\
\text { ft. Drawdown } 95 \mathrm{ft} \\
\text { after } 6 \mathrm{hrs} \text { pump- } \\
\text { ing } 1,500 \mathrm{gal} / \mathrm{min} \\
\text { in } 1945 .\end{array}$ \\
\hline 31 & 3222240865946 & $\begin{array}{l}\text { Dallas Co. } \\
\text { Water } \\
\text { Fire }\end{array}$ & & 780 & & $\mathrm{Kg}$ & 160 & & & & $\mathbf{T}$ & $\mathbf{P}$ & $\begin{array}{l}\text { Reported pump } \\
\text { capacity } 700 \\
\text { gal/min. }\end{array}$ \\
\hline 32 & 3221320865836 & $\begin{array}{l}\text { Dallas Co. } \\
\text { Water } \\
\text { Fire }\end{array}$ & & 820 & & $\mathbf{K g}$ & 160 & & & & $\mathbf{T}$ & $\mathbf{P}$ & $\begin{array}{l}\text { Reported pump } \\
\text { capacity } 700 \\
\text { gal/min. }\end{array}$ \\
\hline 33 & 3203260871810 & $\begin{array}{l}\text { Wilcox Co. } \\
\text { Water } \\
\text { Fire }\end{array}$ & $\begin{array}{l}\text { W.J. } \\
\text { Bozeman }\end{array}$ & 144 & 8 & $\mathbf{K r}$ & 96 & & & & $\mathbf{s}$ & $\mathbf{P}$ & $\begin{array}{l}\text { Casing: } 8 \text { in. fron } \\
\text { surface to } 108 \mathrm{ft} \text {; } \\
6 \text { in. screen from } \\
108 \text { to } 144 \mathrm{ft} \text {. }\end{array}$ \\
\hline 34 & 3152340865924 & $\begin{array}{l}\text { Pine Apple } \\
\text { Water Works }\end{array}$ & $\begin{array}{l}\text { Virginia } \\
\text { Machinery } \\
\text { Co. } \\
1938\end{array}$ & 628 & 8,6 & $\mathbf{K r}$ & 355 & & 219.5 & $7-27-67$ & $\mathbf{s}$ & (1) & $\begin{array}{l}\text { Casing: } 8 \mathrm{in} \text {. fron } \\
\text { surface to } 607 \mathrm{ft} \text {; } \\
6 \mathrm{in} \text {. screen } \mathrm{frcm} \\
607 \text { to } 628 \mathrm{ft} \text {. } \\
\text { Drawdown } 45 \mathrm{ft} \\
\text { after } 15 \mathrm{hrs} \text { pump- } \\
\text { ing } 50 \mathrm{gal} / \mathrm{min} \text {; } 67 \\
\text { ft after } 15 \mathrm{hrs} \\
\text { pumping } 100 \mathrm{gal} / \mathrm{min} \text {. }\end{array}$ \\
\hline
\end{tabular}


Table 1.--Records of public water-supply wel1s and springs in the study area--cont inued

\begin{tabular}{|c|c|c|c|c|c|c|c|c|c|c|c|c|}
\hline $\begin{array}{c}\text { Well } \\
\text { number }\end{array}$ & $\begin{array}{l}\text { Geographic } \\
\text { coordinate } \\
\text { number }\end{array}$ & $\begin{array}{l}\text { Well1 } \\
\text { owner }\end{array}$ & $\begin{array}{l}\text { Driller } \\
\text { and year } \\
\text { drilled }\end{array}$ & $\begin{array}{l}\text { Wel1 } \\
\text { depth } \\
\text { (feet) }\end{array}$ & $\begin{array}{c}\text { Well } \\
\text { diam. } \\
\text { (1nches) }\end{array}$ & $\begin{array}{l}\text { Water } \\
\text { bearing } \\
\text { unit }\end{array}$ & $\begin{array}{l}\text { Altitude } \\
\text { of land } \\
\text { surface }\end{array}$ & $\begin{array}{l}\text { Water level } \\
\text { above }(+) \text { or } \\
\text { below Land } \\
\text { Surface Datun }\end{array}$ & $\begin{array}{l}\text { Date of } \\
\text { measure- } \\
\text { ment }\end{array}$ & $\begin{array}{c}\text { Method } \\
\text { of } \\
\text { lift }\end{array}$ & $\begin{array}{c}\text { Use } \\
\text { of } \\
\text { well }\end{array}$ & Remarks \\
\hline$x=x=x=x$ & 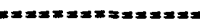 & 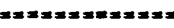 & $x=2 x=2 x=2 x$ & $=x=2 x=x$ & $x=2 x= \pm x=2$ & $x=2=x=2$ & $x=2 x=x=x=$ & 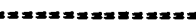 & $x=2 x=2 x$ & $=2 x=2 x=0$ & & 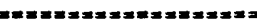 \\
\hline 35 & 3152430870030 & $\begin{array}{l}\text { Pine Apple } \\
\text { Water Works }\end{array}$ & $\begin{array}{l}\text { W.J. } \\
\text { Bozeman } \\
1978\end{array}$ & 492 & 8,4 & $\mathbf{K r}$ & 235 & 108.5 & $5-79$ & $\mathbf{T}$ & $\mathbf{P}$ & $\begin{array}{l}\text { Casing: } 8 \text { in. from } \\
\text { surface to } 460 \mathrm{ft} \text {; } \\
4 \text { in. from } 430 \text { to } \\
460 \mathrm{ftg} 4 \text { in. } \\
\text { screen fram } 460 \text { to } \\
492 \mathrm{ft} \text {. Reported } \\
\text { pump capacity } 150 \\
\text { gal/min. }\end{array}$ \\
\hline 36 & 3200440871708 & $\begin{array}{l}\text { Camden } \\
\text { Water } \\
\text { Sewer }\end{array}$ & $\begin{array}{l}\text { W.J. } \\
\text { Bozenan } \\
1967\end{array}$ & 401 & 8,6 & Kr & 216 & 162.4 & 1968 & $\mathbf{T}$ & p & $\begin{array}{l}\text { Casing: } 8 \text { in. from } \\
\text { surface to } 322 \mathrm{ft} \text {; } \\
6 \text { in. from } 322 \text { to } \\
329 \mathrm{ft} 6 \text { in. } \\
\text { screen fran } 329 \text { to } \\
354 \mathrm{ft} \text {. }\end{array}$ \\
\hline 37 & 3200250871717 & $\begin{array}{l}\text { Camden } \\
\text { Water } \\
\text { Sewer }\end{array}$ & $\begin{array}{l}\text { พ.J. } \\
\text { Bozenan } \\
1963\end{array}$ & 441 & 8 & $\mathbf{k r}$ & 236 & 191.4 & 1963 & $\mathbf{T}$ & $\mathbf{P}$ & $\begin{array}{l}\text { Casing: } 8 \text { in. } \mathrm{frcm} \\
\text { surface to } 336 \mathrm{ft} \text {; } \\
\text { taper seal } 336 \mathrm{to} \\
338 \mathrm{ft} 4 \mathrm{in} \text {. } \\
\text { screen from } 338 \text { to } \\
366 \mathrm{ft} \text {. }\end{array}$ \\
\hline 38 & 3159190872010 & $\begin{array}{l}\text { Camden } \\
\text { Water } \\
\text { Sewer }\end{array}$ & $\begin{array}{l}\text { W.J. } \\
\text { Bozeman } \\
1976\end{array}$ & 390 & 10 & $\mathbf{K r}$ & 225 & 46.8 & $3-76$ & $\mathbf{T}$ & p & $\begin{array}{l}\text { Casing: } 10 \mathrm{in} \text {. } \\
\text { from surface to } \\
334 \mathrm{ft} \text {; } 6 \text { in. } \\
\text { screen ftom } 322 \text { to } \\
390 \mathrm{ft} \text {. }\end{array}$ \\
\hline
\end{tabular}


Table 2.--Goologic units ond thelr water-bearing properties




Table 2.--Geologlc units and thelr water-bearling propertles--Cont I nued

\begin{tabular}{|c|c|c|c|c|c|c|c|c|}
\hline $\begin{array}{l}\text { Era- } \\
\text { them }\end{array}$ & Systen & Serles & Group & $\begin{array}{l}\text { Geologle } \\
\text { unlt }\end{array}$ & $\begin{array}{l}\text { Max Imum } \\
\text { thl ckness } \\
\text { (feet) }\end{array}$ & LIthology & Woter-bearling propert I es & Quallty of woter \\
\hline \multirow{7}{*}{$\begin{array}{l}M \\
0 \\
\text { s } \\
0 \\
2 \\
0 \\
1 \\
c\end{array}$} & \multirow[b]{3}{*}{ C } & \multirow[b]{3}{*}{$\begin{array}{l}\text { U } \\
\text { p } \\
\text { p } \\
\text { - } \\
\text { r }\end{array}$} & \multirow{4}{*}{$\begin{array}{l}\text { s } \\
\bullet \\
1 \\
\text { m }\end{array}$} & $\begin{array}{l}\text { Prolrie } \\
\text { Bluff } \\
\text { Chalk }\end{array}$ & 60 & $\begin{array}{l}\text { silty and sandy tos- } \\
\text { sillterous chalk and } \\
\text { calcareous clay }\end{array}$ & $\begin{array}{l}\text { Relatively Impermeable; not a } \\
\text { source of water. }\end{array}$ & \\
\hline & & & & $\begin{array}{l}\text { RIpley } \\
\text { Format I on }\end{array}$ & $100-300$ & $\begin{array}{l}\text { Flne- to coorse- } \\
\text { gralned glauconltlc } \\
\text { sand, sandy fossill- } \\
\text { farous clay and thin } \\
\text { beds of fossilliferous } \\
\text { calcoreous sandstone } \\
\text { and sendy llmestone }\end{array}$ & 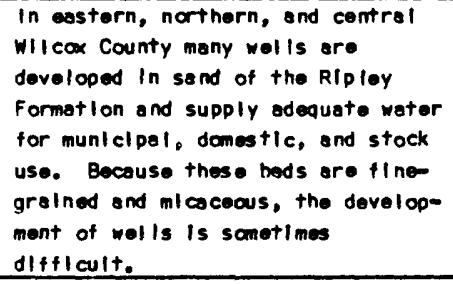 & $\begin{array}{l}\text { Water generally is soft to } \\
\text { moderstely hard and contalins } \\
\text { less than } 250 \mathrm{mg} / \mathrm{L} \text { chloride and } \\
\text { l,000 mg/L dissolved sollds. } \\
\text { Locolly, water contalns Iron in } \\
\text { excess of } 300 \mathrm{ug} / \mathrm{L} \text {. }\end{array}$ \\
\hline & & & & $\begin{array}{l}\text { Demopolls } \\
\text { Chelk }\end{array}$ & 450 & $\begin{array}{l}\text { Foss IIIferous chelk; } \\
\text { sandy slity fossill- } \\
\text { ferous chalk, and } \\
\text { silty fosslilterous } \\
\text { colcareous cloy }\end{array}$ & $\begin{array}{l}\text { Relatively Impermeable; not a } \\
\text { source of water supply. }\end{array}$ & \\
\hline & \multirow[t]{4}{*}{$\begin{array}{l}\text { r } \\
\text { + } \\
\text { : } \\
\text { c } \\
\text { - } \\
\text { u } \\
\text { s }\end{array}$} & \multirow[t]{4}{*}{$\begin{array}{l}c \\
r \\
e \\
+ \\
0 \\
c \\
- \\
0 \\
u \\
\text { s }\end{array}$} & & $\begin{array}{l}\text { Moorev IIlle } \\
\text { Chelk }\end{array}$ & 420 & 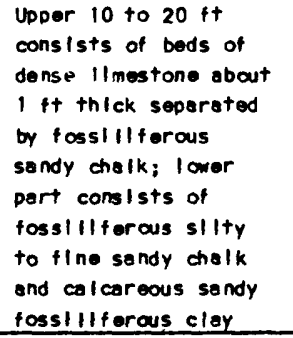 & $\begin{array}{l}\text { Ralatively Imparmeable; not } \\
\text { source of water supply. }\end{array}$ & \\
\hline & & & & $\begin{array}{l}\text { Eutaw } \\
\text { Formation }\end{array}$ & 400 & $\begin{array}{l}\text { Upper part conslsts } \\
\text { of medlummral ined } \\
\text { crossbedded glauco- } \\
\text { nitlc sand Interbedded } \\
\text { with slity clay; lower } \\
\text { part consists of } \\
\text { medlum to very coarse } \\
\text { gralned glouconitle } \\
\text { sand Interbedded with } \\
\text { laminated to thin- } \\
\text { bedded ml caceous } \\
\text { sendy clay }\end{array}$ & $\begin{array}{l}\text { Will yleld } 2 \text { Mgal/d or more to } \\
\text { Indlvidual wells. Excellent } \\
\text { oqulter. } \\
\text {. }\end{array}$ & 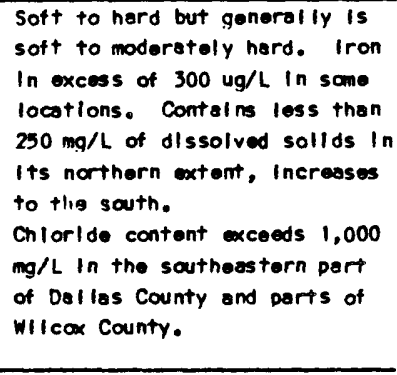 \\
\hline & & & $\begin{array}{l}\mathrm{T} \\
\mathrm{u} \\
\mathrm{s} \\
\mathrm{c} \\
\mathrm{c}\end{array}$ & $\begin{array}{l}\text { Gordo } \\
\text { Formation }\end{array}$ & 400 & $\begin{array}{l}\text { Poorly sorted coarse- } \\
\text { aralned sand and chert } \\
\text { gravel In lower part } \\
\text { of formation; upper } \\
\text { part consists of laml- } \\
\text { nated to massive clay } \\
\text { and lentl cular sand } \\
\text { beds }\end{array}$ & $\begin{array}{l}\text { Will yleld } 1 \text { to } 2 \text { Mgel/d or more } \\
\text { to Individual wells. Excel lent } \\
\text { oquifer. }\end{array}$ & $\begin{array}{l}\text { Soft to moderately herd and } \\
\text { contalns less then } 200 \mathrm{mg} / \mathrm{L} \text { of } \\
\text { dissolved sollds. Commonly } \\
\text { contalns iron in excess of } 300 \\
\text { ug/L. May be suffliclentiy } \\
\text { minerallzed In the southern } \\
\text { extent of the oquifer to be } \\
\text { objectlonsble to other uses. }\end{array}$ \\
\hline & & & $\begin{array}{l}1 \\
0 \\
0 \\
\text { s } \\
0\end{array}$ & $\begin{array}{l}\text { Coker } \\
\text { Formation }\end{array}$ & 1,100 & $\begin{array}{l}\text { Sand, very fline to } \\
\text { coerse gralned; basal } \\
\text { sand } 100 \text { to } 200 \text { ft } \\
\text { thlck and is generally } \\
\text { gravelly. Partly car- } \\
\text { bonaceous sandy clay }\end{array}$ & $\begin{array}{l}\text { Potentlal source of } 1 \mathrm{Mgal} / \mathrm{d} \text { or } \\
\text { more to individusl wells. } \\
\text { Excellemt equlter. }\end{array}$ & $\begin{array}{l}\text { Soft to herd and contalns less } \\
\text { than } 250 \mathrm{mg} / \mathrm{L} \text { of dissolved } \\
\text { sollds in northern part of the } \\
\text { equifer. May be sufflelent Iy } \\
\text { minerallzed to be object l onable } \\
\text { for same uses in the southern } \\
\text { extent of the aqulfer. Iron } \\
\text { levels often exceed } 300 \mathrm{ug} / \mathrm{L} \text {. }\end{array}$ \\
\hline
\end{tabular}


Table 2.--Geologlc unlts and thelr water-bearling propertles--Cont Inued

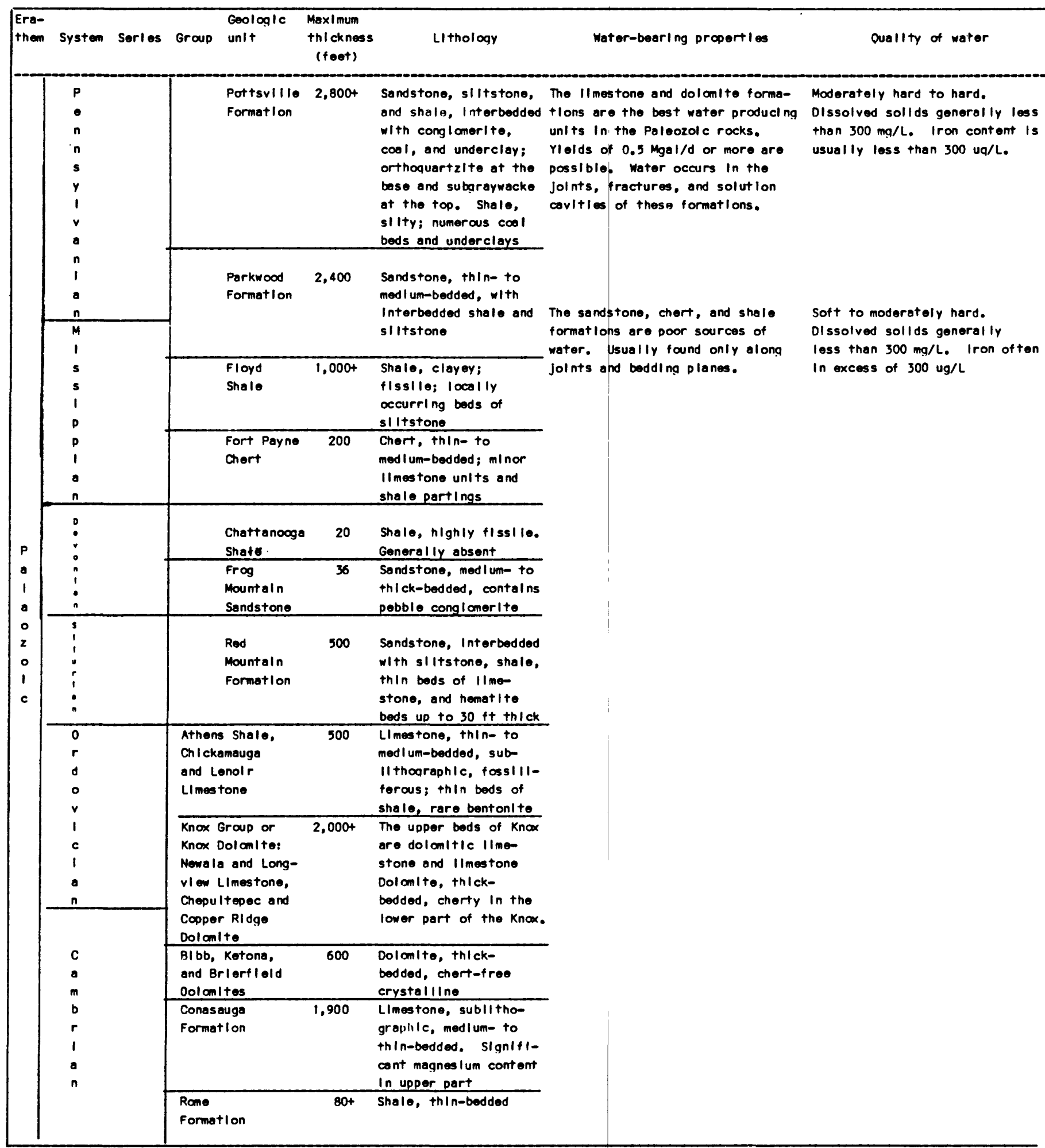

